\title{
尿路感染症の化学療法に関する研究
}

\author{
九州大学医学部泌尿器科学教室 日 高 正 昭
(主任 : 白瀬俊郎教授)
}

\section{STUDIES ON CHEMOTHERAPY OF URINARY TRACT INFECTION}

\author{
Masaaki Hidaka \\ Department of Urology, Faculty of Medicine, Kyushu University (Director: Prof. S. Momose)
}

Chemotherapy plays the most important role in the treatment of urinary tract infections. It is necessary for the effective treatment to classify causative microorganisms and to determine drug sensitivity of the bacteria, and administration of chemotherapeutic agents for the treatment of patients with renal failure should be carefully carried out. The author classified 145 strains of the bacteria cultured from outpatients with urinary tract infection at our clinic from January to December in 1966, and examined their sensitivities to 8 of chemotherapeutic agents. E. coli $(39.3 \%)$ and Staphilococci $(11.1 \%)$ were most frequently found, and they showed high sensitivity to $\mathrm{KM}, \mathrm{CL}$ and NF. The results in the present experiment were compared with the results in the experiments described in our 4 preceding reports, and the same tendency in their results was observed.

$\mathrm{CP}$ and KM were frequently used for the treatment of 52 in-patients with renal failure from 1962 to 1966. Nephrotoxicity of KM has been reported by many authors, and therefore; I observed the effect of KM on renal function, clinically and experimentally at our department. Serum concentration of KM in anuric patients persisted at so high level as $33 \mathrm{mcg} / \mathrm{ml}$ even at 35 th hour after single intramuscular injection of $1.0 \mathrm{gm}$. $24 \%$ in an average of $\mathrm{KM}$, however, was eliminated by hemodialysis for 4 hours from serum whose level was 1 hour after intramuscular injection. Three groups of rabbits were made for the observation of the experiments; 1) normal group, 2) impaired renal function group, 3) infected impaired renal function group, and each group of them was further divided into two subgroups according to dosage of $\mathrm{KM}$, small dosage group $(50 \mathrm{mg} / \mathrm{kg} /$ day) and large dosage group ( $300 \mathrm{mg} / \mathrm{kg} / \mathrm{day})$. Group 1: In the small dosage group, there was no nephrotoxic effect for 20 days. (Group A) In the large dosage group, the mortality caused by $\mathrm{KM}$ was $80 \%$ within 20 days. (Group B) Group 2: In the small dosage group, all were survived for 20 days. (Group C) All were died within 12 days in the large dosage group. (GroupD) Group 3: The rate of survival for 20 days in the small dosage group was $75 \%$, renal infections were not cured, however. (Group E) The mortality in the large dosage group was $80 \%$ for 20 days, and all infections were cured. (Group F) Occurrence of the renal damage which is degeneration of tubular epithelium, caused by $\mathrm{KM}$ is found in individuals in whose serum was accumulated.

In conclusion, to the accumulation of KM in the serum of the patient with renal failure should be paid much attention in case $\mathrm{KM}$ is administered for the treatment.

\section{I. 緒言}

尿路感染症の治療は他の感染症と同様に化学療法が主 体となるが，相ついで登場する化学療法剤もそれぞれ一 長一短があつて，な和切札的㣙、役割を演ずるものがな い。私も尿路感染症の研究に着手して以来, すでに各種

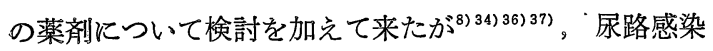
症の化学療法が現在大きな障壁の前に頓座していること を痛感している。
翟この理由として種々の原因があげられるが、いずれに しても宿主側。細菌側, そして薬剤の各方面より根本的 飞再検討し，現在な和最大の武器である化学療法の進む べき道を究明する必要に迫られている。

化学療法が普及するにつれて尿路感染菌は次第に変貌 しつつあり，とくに無批判とも思える抗生剤の乱用によ つて耐性菌の増加が指摘されている。私どもの教室では 1959年以来尿路感染菌の実態について鋭意研究を進め, 
私もすでに1964年および1965年度の調查成績を共同研究 者とともに報告したが35)，今回はさらに1966年度のそれ を加えて綜括し，化学療法剂に対する細菌側の態度が年 次的に如何なる变遷を示しつつあるかを考察し, 現段階 に损ける適正化学療法剤の選択について私見を述べてみ たいと思う。

一方，尿路感染症ではその原因であると，結果である とにかかわらず, 腎機能障害を伴うものが多く，一般感 染症とは異なつた配慮が要望されている. しかしながら このような場合如何なる薬剤をどのような方法で投与す るのが適切であるかは，十分解明されて抢らず，また常 用化学療法剤の中にも腎毒性を示すといら薬剤も指摘さ れていて，一層複雑な問題を提起している。 そこで私は 当教室に和ける過去の化学療法剤の使用状況を調查し, 腎機能害例に括ける化学療法剂の動態を追究し, 尿路感 染症治療に依然有力な薬剤である Kanamycin を中心 に，その腎毒性および腎機能障害時に和ける影響を実験 的に追求したので報告し，諸賢のご批判を仰ぎたいと考 えている.な技本研究は当教室に和ける尿路感染症研究 班の原著として, 占部 ${ }^{54)(55) 56)}$, 熊沢 ${ }^{24)(25)}$, 楢橋 ${ }^{38)}$ につづ くものであるから，その第 7 報として報告する.

\section{II. 尿路感染分離菌とその化学療法㨈感受性}

\section{1. 検查方法拉よび材料}

1966年 1 月より 12 月までの 1 年間に九大泌尿器科外来 を受診し，尿路感染症と診断された，あるいはとれと予 測された患者の一部を対象として，膀胱尿をカテーテル により無菌的に採尿した. 被検尿は一部を遠心沈澱し, 沈椬をメチレンブルウ単染色，グラム染色にて 鏡検し た.さらに尿の一部を用いてハートインフユージョン寒 天平板培地に培養し, $37^{\circ} \mathrm{C}, 18$-24時間後に発育した集 落について鑑別培養を行ない菌種を同定した。な扮腸内
細菌の分類は Kaufman，坂崎 ${ }^{45)}$ のそれに準拠した。 そ れらの菌についてペニシリン $(\mathrm{PC})$ ，ストレプトマイシ ン $(\mathrm{SM})$,クロラムフェニュール $(\mathrm{CP})$, テトラサイクリ ソ (TC),エリスロマイシン (EM), コリスチン (CL), カナマイシン $(\mathrm{KM})$, ニトロフラントイン (Nf) の 8 種 化学療法剤に対する感受性検査を行なつた。な和培地は ハートインフニージョン寒天培地を用い，金沢らの方法 で昭和薬品製の感受性デイスクを用いた。

2. 検查成績

1）尿路感染症より分離された菌

検出菌は 145株であり，大別すると球菌37株 (25.6 $\%)$,桿菌97株 (66.9\%), 不明菌11株 ( $7.6 \%)$ である. その内訳は大腸菌57株 $(39.3 \%)$,変形菌10株 ( $6.9 \%)$, 緑膿菌 5 株 ( $3.4 \%)$,アクロモバクター3株, クレブジ エラ 2 株, クロアカ, アルカリ糞便菌扔の打の 1 株, グ ラム陰性桿菌17株, ブドウ球菌16株 (11.1\%), レンサ球 菌 1 株, グラム陽性球菌19株, 不詳桿, 球菌扔の和の 1 株, 不明菌11株となつた (第 1 表).

a ) 分離菌の疾患別発現頻度

尿路感染症を 4 群に大別し, その各群より分離された 菌の種類を検討してみた。

i ) 膀脱炎

分離された菌は94株であり大腸菌37株（38.1）,ブドウ 球菌11株 $(11.7 \%)$, 変形菌 6 株 $(6.4 \%)$, 緑膿菌 4 株 ( $4.3 \%)$,アクロモバクター, アルカリ翼便菌抒の拉の 1 株, クレブジェラ 2 株, グラム陰性桿菌12株, 不詳桿 菌 1 株, レンサ球菌 1 株, グラム陽性球菌 11 株, 不詳球 菌 1 株, 不明菌 6 株となつている。

ii ) 腎孟腎炎

分離された菌は37株であり大腸菌14株 $(37.8 \%)$,ブド ウ球菌 4 株 ( $1.1 \%)$, 変形菌, クロアカ, アクロモバク

第 1 表 尿路感染分離菌（1966年）

\begin{tabular}{|c|c|c|c|c|c|c|c|c|c|c|c|c|c|c|c|}
\hline 疾患 & $\mid$\begin{tabular}{ll|}
$\mid$ 菌 & 球 \\
\end{tabular} & $\begin{array}{l}\text { 連銷 } \\
\text { 球囷 }\end{array}$ & $\left|\begin{array}{ll}\text { グラム } \\
\text { 陽 } & \text { 性 } \\
\text { 球 } & \text { 菌 }\end{array}\right|$ & $\begin{array}{l}\text { 不詳 } \\
\text { 球菌 } \\
\end{array}$ & 大腸菌 & 変形菌 & 緑膿菌 & $\begin{array}{l}\eta \square \\
\text { アカ }\end{array}$ & \begin{tabular}{|l|} 
7ク口 \\
モバク \\
タ \\
\end{tabular} & \begin{tabular}{|l|} 
了ルカ \\
便性資 \\
\end{tabular} & $\begin{array}{l}\eta レ 7 \\
\text { ジェ }\end{array}$ & $\mid \begin{array}{ll}\text { グラム } \\
\text { 陰 } \\
\text { 悍 } & \text { 菌 } \\
\end{array}$ & \begin{tabular}{|l} 
不譊 \\
桿菌
\end{tabular} & 不明菌 & 計 \\
\hline 膀 胱 炎 & 11 & 1 & 11 & 1 & 37 & 6 & 4 & & 1 & 1 & 2 & 12 & 1 & 6 & 94 \\
\hline 腎孟腎炎 & 4 & & 7 & & 14 & 1 & & 1 & 1 & & & 5 & & 4 & 37 \\
\hline 十篣搵督炎 & 1 & & 1 & & 4 & 2 & 1 & & 1 & & & & & 1 & 11 \\
\hline 尿道炎 & & & & & 2 & 1 & & & & & & & & & 3 \\
\hline 計 & $\mid \begin{array}{c}16 \\
(11.1)\end{array}$ & 1 & 19 & 1 & $\begin{array}{c}57 \\
(39.3) \\
\end{array}$ & $\begin{array}{l}10 \\
(6.9) \\
\end{array}$ & 5 & 1 & 3 & 1 & 2 & 17 & 1 & 11 & 145 \\
\hline
\end{tabular}

( ) $は \%$ 


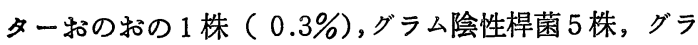
么陽性球菌 7 株, 不明菌 4 株であつた。

iii）膀脱炎十腎盂腎炎

上部・下部尿路ともに感染のみられたものをまとめる 之，分離菌数は11株であり，大腸菌 4 株 (36.3\%),変形 菌 2 株, 緑膿菌, アクロモバクター,ブドウ球菌, グラ 么陽性球菌, 不明菌打の打の 1 株であつた。

iv）尿道炎

尿道に限局された非特異性炎症からは 3 株が分離さ れ，大腸菌 2 株，変形菌 1 株であつた。

b ）年次的変遷

以上の成績を当教室に拈ける以前の報告, すなわち 1959年 ${ }^{54}$ (154株)，1961年 ${ }^{24)}$ (215株)，1964・65年(435 株）のそれと菌種別の発現頻度を比較してみると次のご とくである.

まずブドウ球菌は45.5\%より $32.1 \% ， 14.8 \% ， 11.1 \%$ と年々減少している。次に大腸菌は $19.1 \%$ より $13.0 \%$ と 一時減少したが 1964 ・65年には37.9\%と著明に増加し， 今回も $39.3 \%$ と若干の増加をみている。な和変形菌は
$9.7 \% \rightarrow 6.5 \% \rightarrow 7.3 \% \rightarrow 6.9 \% \rightarrow$ あまり変動がな く，緑膿菌は $3.2 \% \rightarrow 12.1 \% \rightarrow 4.0 \% \rightarrow 3.4 \%$ と一時的 に増加がみられたが，あとはほとんど変動がないこれ らを総括して示すと第 1 図のごとくである。

2）分離菌の化学療法剂感受性

検査方法の項で述べたごとく，8種類の化学療法剂に 対する感受性検査を前項に記載した 145株について行な つた。発現頻度の高いブドウ球菌, 大腸菌, 変形菌, 緑 膿菌の 4 種について年次的にまとめた結果は次のとおり である。

a ）囷種別年度別感受性検查成績

i ) ブドウ球菌

第 2 表のごとく高度感受性菌がもつとも多いのは KM の60\%であり，次いで CP の57\%である。以下 EM 46 $\%, \mathrm{TC} 40 \%, \mathrm{Nf} 33 \%, \mathrm{SM} 27 \%, \mathrm{CL} 14 \%, \mathrm{PC} 7 \%$ の順になつている。

高度感受性菌と中等度感受性菌を合わせると, やはり KM の $80 \%$ が最高を示し，Nfにも $79 \%$ と感受性率 が高い. SM, CP, EM には60\%台の感受性を示し,

第 2 表 ブドウ球菌の 8 種化学療法剤に対する感受性

$\begin{array}{ll}1959 & 70 \text { 株 } \\ 1961 & 69 \text { 株 } \\ 1964-1965 & 65 \text { 株 } \\ 1966 & 15 \text { 株 }\end{array}$

\begin{tabular}{|c|c|c|c|c|c|c|c|c|c|}
\hline & 年 & P C & S M & C P & $\mathrm{TC}$ & EM & C L & $\mathbf{K M}$ & N F \\
\hline \multirow{4}{*}{-} & 1959 & $24(33)$ & $17(21)$ & $6(9)$ & $9(13)$ & $4(6)$ & $24(37)$ & & \\
\hline & 1961 & $30(43)$ & $14(21)$ & $6(9)$ & $11(16)$ & $6(9)$ & $27(39)$ & $2(3)$ & \\
\hline & $1964-1965$ & $19(29)$ & $22(34)$ & $14(22)$ & $9(14)$ & $9(14)$ & $19(30)$ & $6(10)$ & $9(16)$ \\
\hline & 1966 & $10(67)$ & $5(33)$ & $3(21)$ & 0 & $5(33)$ & $9(60)$ & 0 & 0 \\
\hline \multirow{4}{*}{+} & 1959 & $15(21)$ & $9(11)$ & $5(7)$ & $18(27)$ & $4(6)$ & $16(25)$ & & \\
\hline & 1961 & $12(17)$ & $9(13)$ & $4(6)$ & $20(29)$ & $3(4)$ & $15(22)$ & $2(3)$ & \\
\hline & $1964-1965$ & $13(20)$ & $9(15)$ & $13(20)$ & $17(27)$ & $11(18)$ & $14(22)$ & $9(14)$ & $10(16)$ \\
\hline & 1966 & $3(20)$ & $1(7)$ & $2(14)$ & $8(53)$ & $1(7)$ & $1(7)$ & $3(20)$ & $3(20)$ \\
\hline \multirow{4}{*}{ H } & 1959 & $16(22)$ & $17(21)$ & $7(10)$ & $9(13)$ & $7(10)$ & $12(19)$ & & \\
\hline & 1961 & $15(22)$ & $18(26)$ & $11(17)$ & $13(19)$ & $5(7)$ & $12(17)$ & $2(3)$ & \\
\hline & $1964-1965$ & $13(20)$ & $13(20)$ & $10(16)$ & $12(19)$ & 11 (18) & $15(24)$ & $19(30)$ & $29(47)$ \\
\hline & 1966 & $1(7)$ & $5(33)$ & $1(7)$ & $1(7)$ & $2(14)$ & $3(20)$ & $3(20)$ & $7(46)$ \\
\hline \multirow{4}{*}{ H } & 1959 & $17(24)$ & $37(46)$ & $51(74)$ & $31(46)$ & $53(78)$ & $13(20)$ & & \\
\hline & 1961 & $12(17)$ & $28(41)$ & $48(69)$ & $25(36)$ & $55(80)$ & $15(22)$ & $63(91)$ & \\
\hline & $1964-1965$ & $20(31)$ & $20(31)$ & $27(42)$ & $25(40)$ & $32(50)$ & $15(24)$ & $29(46)$ & $13(21)$ \\
\hline & 1966 & $1(7)$ & $4(27)$ & $8(57)$ & $6(40)$ & $7(46)$ & $2(14)$ & $9(60)$ & $5(33)$ \\
\hline \multirow{4}{*}{$\begin{array}{c}(+\mathrm{H}) \\
+ \\
(\mathrm{H})\end{array}$} & 1959 & $(46)$ & (67) & (84) & (59) & (88) & (39) & & \\
\hline & 1961 & (39) & (67) & $(86)$ & (55) & (87) & (39) & $(94)$ & \\
\hline & $1964-1965$ & (51) & (51) & (58) & (59) & (68) & $(48)$ & $(76)$ & (68) \\
\hline & 1966 & (14) & $(60)$ & (64) & (47) & $(60)$ & (33) & $(80)$ & $(79)$ \\
\hline
\end{tabular}


第 3 表 大腸菌の 8 種化学療法剤に対する感受性

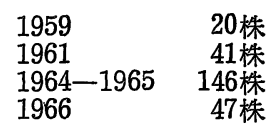

\begin{tabular}{|c|c|c|c|c|c|c|c|c|c|}
\hline & 年 & $\mathrm{PC}$ & $\mathbf{S M}$ & C P & T C & EM & C L & $\mathrm{KM}$ & N F \\
\hline \multirow{4}{*}{-} & 1959 & $17(85)$ & $5(31)$ & $5(25)$ & $8(40)$ & $12(60)$ & $3(17)$ & & \\
\hline & 1961 & $29(71)$ & $4(10)$ & $10(24)$ & $18(44)$ & $22(54)$ & $3(7)$ & 0 & \\
\hline & $1964-1965$ & $103(70)$ & $61(42)$ & $53(37)$ & $47(32)$ & $20(15)$ & $10(8)$ & $10(7)$ & $18(13)$ \\
\hline & 1966 & $46(98)$ & $29(63)$ & $25(56)$ & $22(47)$ & $5(11)$ & 0 & $1(2)$ & $2(4)$ \\
\hline \multirow{4}{*}{+} & 1959 & $2(10)$ & $2(13)$ & $2(10)$ & $1(5)$ & $6(30)$ & $3(17)$ & & \\
\hline & 1961 & $4(10)$ & $15(37)$ & $1(3)$ & $1(3)$ & $13(32)$ & $6(15)$ & $1(3)$ & \\
\hline & $1964-1965$ & $18(12)$ & $33(22)$ & $15(10)$ & $24(16)$ & $69(47)$ & $19(13)$ & $15(10)$ & $38(24)$ \\
\hline & 1966 & 0 & $5(11)$ & $1(2)$ & $8(17)$ & $26(55)$ & $3(6)$ & $3(6)$ & $8(18)$ \\
\hline \multirow{4}{*}{ H } & 1959 & 0 & $5(31)$ & $4(20)$ & $8(40)$ & $1(5)$ & $3(17)$ & & \\
\hline & 1961 & $1(2)$ & $9(22)$ & $8(20)$ & $11(27)$ & $5(13)$ & $6(15)$ & $19(46)$ & \\
\hline & $1964-1965$ & $13(9)$ & $34(24)$ & $35(24)$ & $33(23)$ & $34(23)$ & $59(40)$ & $82(57)$ & $63(44)$ \\
\hline & 1966 & 0 & $5(11)$ & $5(11)$ & $3(6)$ & $13(28)$ & $14(30)$ & $27(59)$ & $30(67)$ \\
\hline \multirow{4}{*}{ 卅 } & 1959 & $1(5)$ & $4(25)$ & $9(45)$ & $3(15)$ & $1(5)$ & $9(50)$ & & \\
\hline & 1961 & $7(17)$ & $13(32)$ & $22(54)$ & $11(27)$ & $1(2)$ & $26(63)$ & $21(51)$ & \\
\hline & $1964-1965$ & $12(9)$ & $18(12)$ & $42(29)$ & $41(29)$ & $22(15)$ & $58(39)$ & $39(26)$ & $24(19)$ \\
\hline & 1966 & $1(2)$ & $7(15)$ & $14(31)$ & $14(30)$ & $3(6)$ & $30(64)$ & $15(33)$ & $5(11)$ \\
\hline \multirow{4}{*}{$\begin{array}{l}(+4) \\
(+4)\end{array}$} & 1959 & (5) & $(56)$ & (65) & $(55)$ & (10) & (67) & & \\
\hline & 1961 & (19) & $(54)$ & (74) & (54) & (15) & (78) & (97) & \\
\hline & $1964-1965$ & (18) & (36) & (53) & (52) & (38) & (79) & (83) & (63) \\
\hline & 1966 & (2) & $(26)$ & $(42)$ & (36) & (34) & (94) & (92) & (78) \\
\hline
\end{tabular}

( ) 内は\%

第 4 表 变形菌の 8 種化学㙩法剤に対する感受性

$\begin{array}{ll}1959 & 15 \text { 株 } \\ 1961 & 14 \text { 株 } \\ 1964-1965 & 27 \text { 株 } \\ 1966 & 10 \text { 株 }\end{array}$

\begin{tabular}{|c|c|c|c|c|c|c|c|c|c|}
\hline & 年 株 & P C & S M & C P & $\mathrm{TC}$ & EM & C L & $\mathrm{KM}$ & N F \\
\hline \multirow{4}{*}{-} & 1959 & $10(63)$ & $4(33)$ & $6(43)$ & $7(50)$ & $9(69)$ & $9(69)$ & & \\
\hline & 1961 & $14(100)$ & $8(57)$ & $9(64)$ & $8(57)$ & $6(43)$ & $6(43)$ & $2(14)$ & \\
\hline & $1964-1965$ & $19(70)$ & $15(58)$ & $10(38)$ & $7(26)$ & $15(58)$ & $16(60)$ & $3(12)$ & $18(68)$ \\
\hline & 1966 & $10(100)$ & $6(60)$ & $3(30)$ & $3(30)$ & $5(50)$ & $8(80)$ & $2(20)$ & $5(50)$ \\
\hline \multirow{4}{*}{+} & 1959 & $5(31)$ & $1(8)$ & $2(14)$ & $4(29)$ & $3(23)$ & $3(23)$ & & \\
\hline & 1961 & 0 & $1(7)$ & $3(22)$ & $4(29)$ & $5(36)$ & $3(22)$ & $5(36)$ & \\
\hline & $1964-1965$ & $5(18)$ & $2(8)$ & $3(12)$ & $15(58)$ & $9(34)$ & $3(12)$ & $6(24)$ & $5(20)$ \\
\hline & 1966 & 0 & 0 & $1(10)$ & $4(40)$ & $3(30)$ & 0 & 0 & $3(30)$ \\
\hline \multirow{4}{*}{ H } & 1959 & $1(6)$ & $3(25)$ & $5(36)$ & $2(14)$ & 0 & 0 & & \\
\hline & 1961 & 0 & $4(29)$ & $1(7)$ & $1(7)$ & $2(14)$ & $2(14)$ & $3(22)$ & \\
\hline & $1964-1965$ & $2(8)$ & $5(20)$ & $7(26)$ & $2(8)$ & $2(8)$ & $4(16)$ & $12(48)$ & $3(12)$ \\
\hline & 1966 & 0 & $1(10)$ & $1(10)$ & $1(10)$ & $2(20)$ & 0 & $7(70)$ & $1(10)$ \\
\hline \multirow{4}{*}{ 冊 } & 1959 & 0 & $4(33)$ & $1(7)$ & $1(7)$ & $1(8)$ & $1(8)$ & & \\
\hline & 1961 & 0 & $1(7)$ & $1(7)$ & $1(7)$ & $1(7)$ & $3(22)$ & $4(29)$ & \\
\hline & $1964-1965$ & $1(4)$ & $4(16)$ & $6(24)$ & $2(8)$ & 0 & $3(12)$ & $4(16)$ & 0 \\
\hline & 1966 & 0 & $3(30)$ & $5(50)$ & $2(20)$ & 0 & $2(20)$ & $1(10)$ & $1(10)$ \\
\hline
\end{tabular}




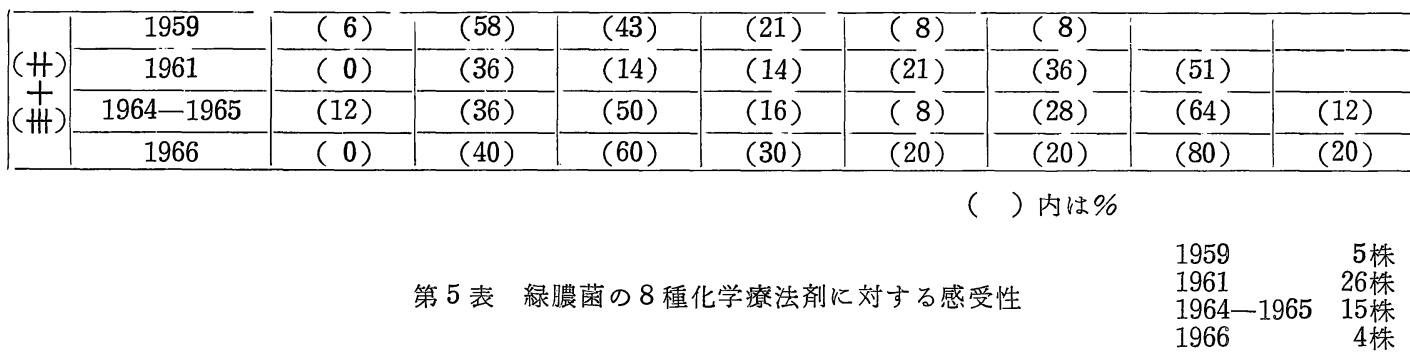

\begin{tabular}{|c|c|c|c|c|c|c|c|c|c|}
\hline & 年 & P C & $\mathrm{S} M$ & C P & $\mathrm{TC}$ & $\mathrm{EM}$ & $C L$ & $\mathrm{KM}$ & N F \\
\hline \multirow{4}{*}{ - } & 1959 & $5(100)$ & $3(75)$ & $2(40)$ & $1(20)$ & $4(80)$ & $3(60)$ & & \\
\hline & 1961 & $22(85)$ & $21(81)$ & $16(62)$ & $10(39)$ & $9(35)$ & $2(8)$ & $7(27)$ & \\
\hline & $1964-1965$ & $14(93)$ & $13(86)$ & $6(40)$ & $7(50)$ & $8(53)$ & $4(26)$ & $9(60)$ & $13(86)$ \\
\hline & 1966 & $4(100)$ & $2(50)$ & $3(75)$ & 0 & $4(100)$ & $1(25)$ & $2(50)$ & $4(100)$ \\
\hline \multirow{4}{*}{+} & 1959 & 0 & 0 & $2(40)$ & $3(60)$ & 0 & 0 & & \\
\hline & 1961 & $4(15)$ & $2(8)$ & $6 \overline{(23)}$ & $10(39)$ & $13(50)$ & $2(8)$ & $11(42)$ & \\
\hline & $1964-1965$ & $1(7)$ & $1(7)$ & $3(20)$ & $3(22)$ & $5(31)$ & $3(20)$ & $4(26)$ & $1(7)$ \\
\hline & 1966 & 0 & $2(50)$ & $1(25)$ & $4(100)$ & 0 & 0 & $2(50)$ & 0 \\
\hline \multirow{4}{*}{ H } & 1959 & 0 & 0 & 0 & 0 & $1(20)$ & 0 & & \\
\hline & 1961 & 0 & $2(8)$ & $3(12)$ & $4(15)$ & $2(8)$ & $7(27)$ & $2(8)$ & \\
\hline & $1964-1965$ & 0 & $1(7)$ & $3(20)$ & $2(14)$ & $2(14)$ & $2(14)$ & $1(7)$ & $1(7)$ \\
\hline & 1966 & 0 & 0 & 0 & 0 & 0 & 0 & 0 & 0 \\
\hline \multirow{4}{*}{ 卅 } & 1959 & 0 & $1(25)$ & $1(20)$ & $1(20)$ & 0 & $2(40)$ & & \\
\hline & 1961 & 0 & $1(4)$ & $1(4)$ & $2(8)$ & $2(8)$ & $15(58)$ & $6(23)$ & \\
\hline & $1964-1965$ & 0 & 0 & $3(20)$ & $2(14)$ & 0 & $6(40)$ & $1(7)$ & 0 \\
\hline & 1966 & 0 & 0 & 0 & 0 & 0 & $3(75)$ & 0 & 0 \\
\hline \multirow{4}{*}{$\begin{array}{c}(\mathrm{H}) \\
+ \\
(\mathrm{H})\end{array}$} & 1959 & $(0)$ & (25) & (20) & $(20)$ & (20) & $(40)$ & & \\
\hline & 1961 & $(0)$ & (12) & (16) & (23) & (16) & (85) & (31) & \\
\hline & $1964-1965$ & $(0)$ & ( 7$)$ & (40) & $(28)$ & (14) & (54) & (14) & ( 7$)$ \\
\hline & 1966 & $(0)$ & $(0)$ & $(0)$ & $(0)$ & $(0)$ & $(75)$ & $(0)$ & $(0)$ \\
\hline
\end{tabular}

（）内は\%

第 1 図。尿路分離菌の年次的変遷

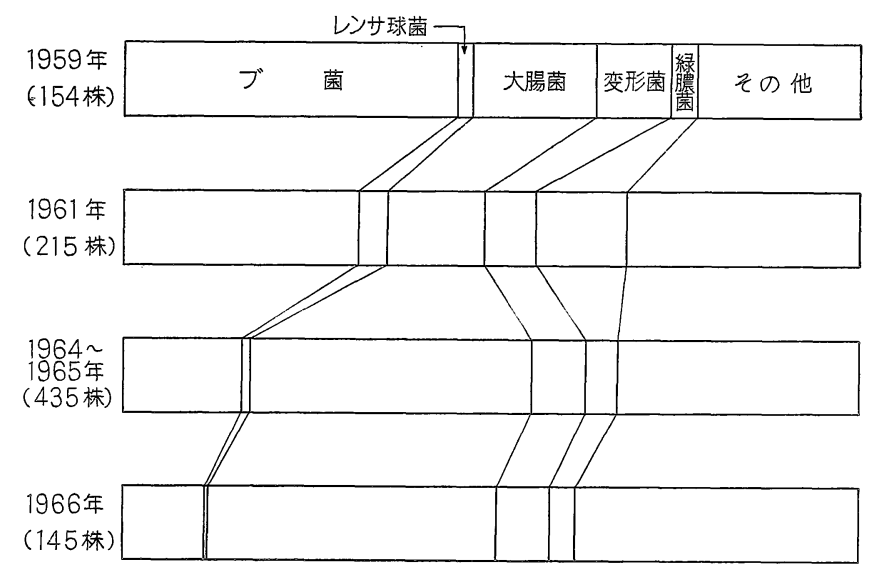


PC，CL にはそれぞれ14\%，33\%と低くなつている。而 性菌についてみると，PC，CL には逆に67\%，60\%と高 值を示し, TC, KM, Nf には0\%であつた。

\section{ii ) 大腸菌}

第 3 表に示すごとく高度感受性菌がもつとも多いのは CL の64\%であり, 次いで KM 33\%, CP 31\%, TC 30\%である. SM, Nf, EM, PC にはそれぞれ $15 \%, 11$ $\% ， 6 \% ， 2 \%$ と低い值を示している. 高度感受性菌十 中等度感受性菌ではやはり CLに $94 \%$ と最高値を示し， 次いで KM に $92 \%$ と者が群を抜いて良い。以下 $\mathrm{Nt}$ $78 \%$, CP $42 \%$, TC $36 \%$, EM 34\%, SM $26 \%$, PC $2 \%$ となつてる.

耐性菌についてみるとPC には 98\%とほとんど完全 耐性を示し，SM 63\%，CP 56\%，TC 47\%となつてい るが，耐性の少ない方からみると CL $0 \%, \mathrm{KM} 2 \%$ ， Nf 4\%，EM 11\%となり EM を除いては感受性率の 順になつている.

iii) 変形菌

第 4 表に示すごとく高度感受性菌は CP $50 \%$, SM 30 $\%$, TC, CL $20 \%$, KM, Nf 10\%, PC, CL 0\%となつ て全般的に感受性率が低い. 高度感受性十中等度感受性 では KM の80\%が最高となり,次いで CP $60 \%$ が良く， 以下 SM 40\%, TC 30\%, EM, CL, Nf 际の执の $20 \%$ と低く，PC には0\%である. 耐性菌をみると PC に完 全耐性を示し，次いで CL 80\%が多い，以下それぞれ SM $60 \%$, EM, Nf 50\%, CP, TC 30\%, KM 20\%と なつて $\mathrm{KM}$ の耐性が一番少ない。

iv) 緑膿菌

第 5 表に示すごとく少数にすぎないが，CL に高度感 受性を示すのみで，他の 7 種には感受性がない.なお TC には完全耐性の菌はなく，CL には25\%の耐性を示 した。

b ) 年次的変遷

高度感受性菌と中等度感受性菌を合わせたものを感受 性菌として前 3 回の報告と比較してみた。

i ) ブドウ球菌

第 2 図に示すごとく前年度より感受性が増加したるの はSM, CP，KM，Nfである. 低下したものはPC，TC， EM，CLであるが，特に PC には37\%と大幅に低下し， EM は年次的に低下している. 総体的に見てブドウ球菌 の薬剤に対する感受性は低下して来ていると云えよう。 Nf については1964年以降から検査しているのみで明確 なことは云えない。
第 2 図.ブドウ球菌の年度別感受性率

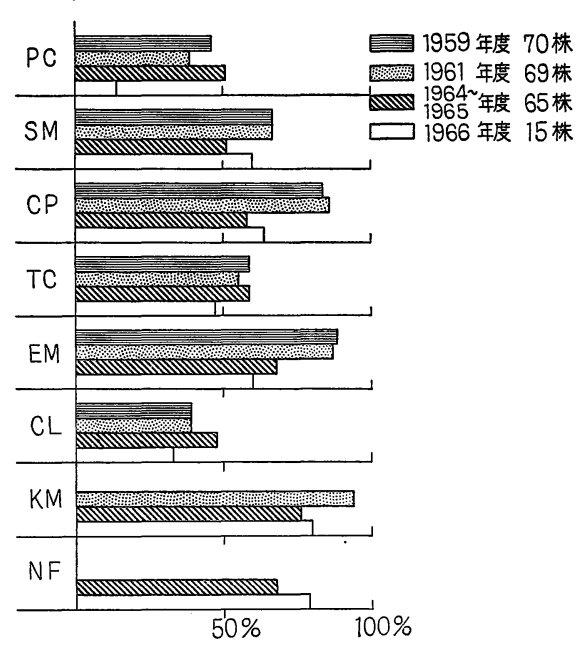

第 3 図．大腸菌の年度別感受性率

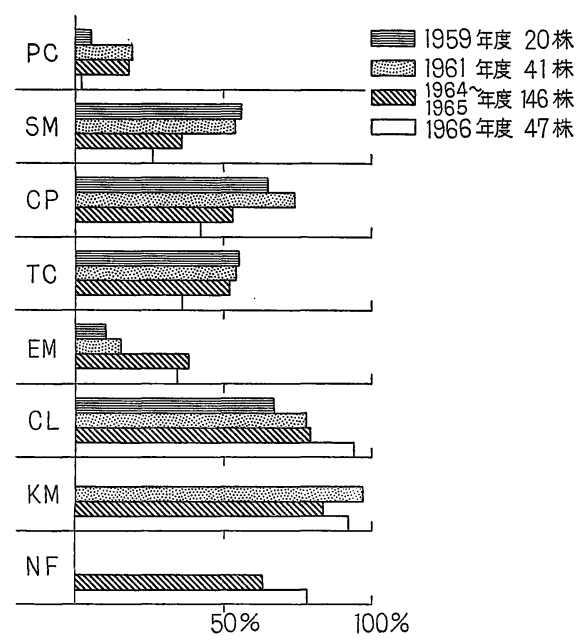

ii ) 大腸菌

第 3 図に示すごとく PC, SM, CP, TC に対する感受 性は漸減の傾向にあり，特に TC には今回は $16 \%$ と大幅 飞低下している．EM には前回までは漸増したが，今回 はやや低下している。CL，Nf には増加を示し，KM に 対しては変動しつつ漸減の傾向にあるが，依然として高 い感受性を示している.

iii) 変形菌

第 4 図に示すごとくPC，EM に対しては一定の傾向は 見られない，一時的に低下，以後漸増の形を示するのに $\mathrm{SM}, \mathrm{CP}, \mathrm{TC}$ があり，CL には一時的に増加し以後は 
第 4 図. 変形菌の年度別感受性率

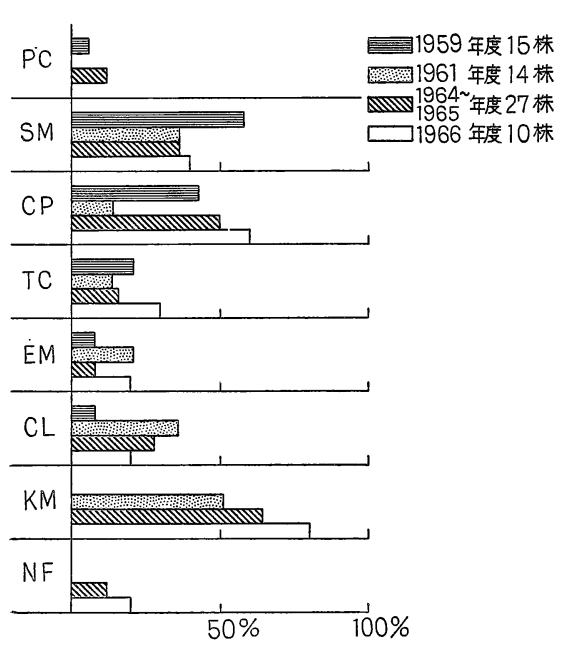

第 5 図。緑膿菌の年度別感受性率

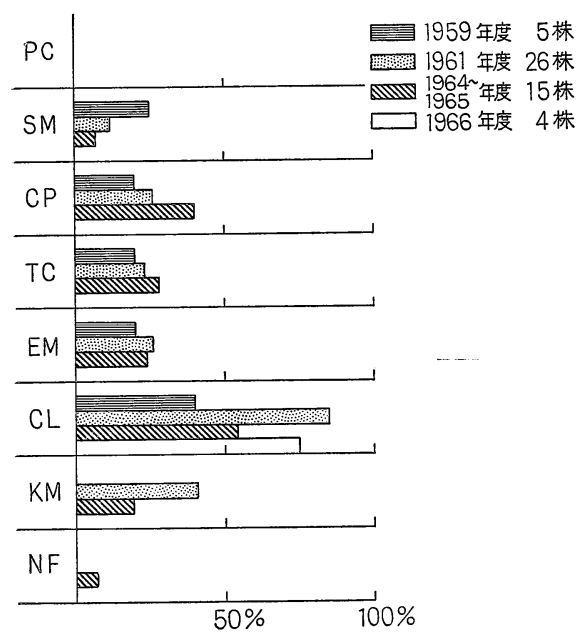

漸减している。 KM, Nf には增加を示しているが。 Nf には増加したとは云兄高々 $20 \%$ の感受性率である。総体 的には KM, CP に感受性が高い。

iv) 緑膿菌

第 5 図のごと 。 CL に対しては変動はあるが高い感 受性を示している。SM, KM には漸減， CP, TC 飞は 漸増と二つの型に大別出来るが，いずれにしても感受性 率50\%以下のレベルでの変動である．PC には1959年度 より1966年度までに 1 株も感受性を示していない。

3. 考察

尿路感染症の治療においては宿主側の条件で勘案しなけ
ればならないと同時に, 他の感染症一般 と同様, 起炎 菌の種類，その出現頻度およびその薬剤に対する感受性 の状態を把握することが極めて重要である。

すでにわれわれの教室では1959年 ${ }^{54)}, 1961$ 年 $^{24)}, 1965$ 年 ${ }^{35)}$ 亿詳細な報告を行なつて来ているが, 私はここにさ らに1966年度の報告を加え, 前 3 回の報告と対比させて みた。

尿路感染症患者より分離される菌の発現頻度は対象と なる疾患の種頑, 加療の有無, 病期によつてかなり違つ たものになつて来ると考兄られるが，参考として他の報 告を見てみる。

まず本邦の報告例では西村 ${ }^{399}$ は大腸菌, ブドウ球菌。 緑膿菌, 変形菌の順に多いとし, 志田 ${ }^{47}$ によればブドウ 球菌, 大腸菌, 緑膿菌, 変形菌の順であり, 吉田 ${ }^{60}$ は大 腸菌, ブドウ球菌, 変形菌, 肺桿菌の順と云い, 福井 ${ }^{10)}$, 久世 ${ }^{30)}$, 百瀬 ${ }^{35)}$, 牧野 ${ }^{31)}$, 高安 ${ }^{511}$ は大腸菌が最も多く, 次いでブドウ球菌と述べ，黒川 ${ }^{29)}$, 占部 ${ }^{54)}$, 熊沢 ${ }^{24)}$, 大 井 ${ }^{43)}$ はブドウ球菌が最多で，次に大腸菌が多く見られた と報告している。

また高井 ${ }^{50)}$, 小林 ${ }^{23)}$, 山本 ${ }^{59}$ は大腸菌が最も多いと し, 河田 ${ }^{20)}$ は大腸菌, 緑膿菌の順であると述べている. 一方外国の例を見ると Herrold ${ }^{13)}$ は大腸菌50\%，変形 菌，腸球菌がそれぞれ $25 \%$ であつたと云い，Bush ${ }^{6)} ら$

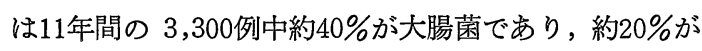
Klebsiella-Aerobactorであつたと報告し，Seneca ${ }^{46)}$ は 40〜50\%が大腸菌であり。次いで Klebsiella, Proteus が多いとしている。

全般的に見ると本邦では大腸菌, ブドウ球菌の順に多 いと云う報告と，ブドウ球菌，大腸菌と順序が逆になつ た報告が相半ばしているが，外国の例では大腸菌が多 く,ブドウ球菌の占める割合は非常に低いようである。

今回の私の成績は大腸菌が40\%ともつとも多く, 次い でグラム陽性球菌, グラム陰性桿菌, ブドウ球菌，不明 菌, 変形菌, 緑膿菌の順になつているが, これをブドウ球 菌を含めたグラム陽性球菌とグラム陰性桿菌に大別して みると，第 6 図のごとく，外来患者の 145 株ではその比 が $24.9 \%$ 対 $66.2 \%$ とないてる。入院患者から分離した 245株で同様に比較してみると,グラム陽性球菌対グラ ム陰性桿菌の比は $9.8 \%$ 対 $78.4 \%$ となつて Herrold ${ }^{13)}$, Bush $^{6)}$ 。Seneca ${ }^{46)}$ の報告と類似しているようである。

次に分離菌の疾患別頻度を見ると, 膀胱炎では大腸菌 が37株と最も多く，次いでブドウ球菌を含むグラム陽 性球菌が22株となつている。変形菌は 6 株, 緑膿菌は 4 
第 6 図. 尿路感染分離菌（1966年）

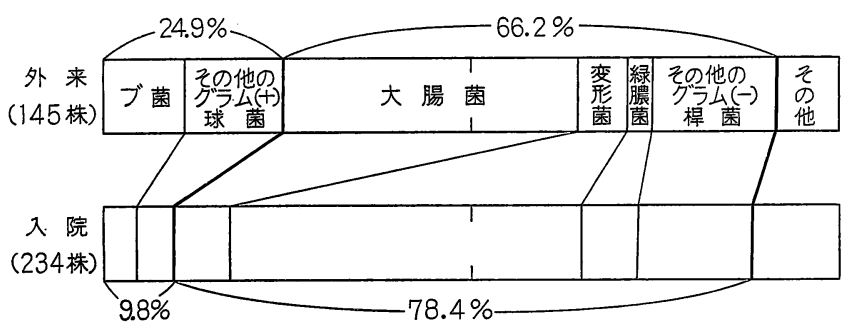

株である.グラム陽性球菌とグラム陰性桿菌を比較して みると23株対 64 株で後者が約 3 倍である. 腎孟腎炎でも 大腸菌が14株で最も多くみられている。

分離菌の年次的推移についてみると,ブドウ球菌は 年々減少し, 逆に大腸菌が増加している.1959年の占 部 ${ }^{54)}$ の報告と比較するとブドウ球菌・大腸菌の発現率が 逆転している. 変形菌の出現率は大きな変動を示さず, 緑膿菌は1961年度に $3.2 \%$ より $12.1 \%$ と大幅に増加した が, その後は $4.0 \%, 3.4 \%$ と著明な変動はない. 杉村 $49 \%$ によると1962～1965年の 4 年間に桿菌は $52.9 \%$ り漸増 の傾向を示して $85.7 \%$ に達し, 球菌は $36.8 \%$ より $6.6 \%$ と著明に減少していると云う. Bush ${ }^{6)}$ らは11年間の分 離菌の変遷で，大腸菌が $51 \%$ より漸次減少して $29 \%$ と なり，ブドウ球菌を含むグラム陽性球菌も25\%より $13 \%$ と減少傾向を示して扣り, 変形菌はやや増加し, 緑膿菌 は注ぼ10\%前後であるが, Klebsiella-Aerobactor が10 \%弱から約 $25 \%$ へ増加したことは特記すべきことである と述べている.

尿路感染症患者より分離された細菌については前述の ごとく, PC, SM, CP, TC, EM, CL, KM, Nf の 8 種 化学療法剤にに対する感受性検査を行なつてみた。

大腸菌の薬剤感受性は岡 ${ }^{42}$, 西村 ${ }^{39}$, 大井 ${ }^{43)}$, 久世 ${ }^{30)}$, 古沢 ${ }^{11)}$ らは KM に対して最も良いと報告し, 西浦 ${ }^{40)}$, 熊沢 ${ }^{24)}$, 稲田 ${ }^{16)}$, 杉村 ${ }^{49)}$, 百瀬 ${ }^{35)}$ は KM に最も高く, 次いで CL であると述べている．また高井 ${ }^{50}$ は1962〜 1964年の 3 年間には KM, CL 飞感受性が高く, しか子 年々耐性菌の出現率が低下していると報告している. 加藤 $^{18)}$ ，河田 ${ }^{20)}$ も $\mathrm{KM}, \mathrm{Nf}, \mathrm{CL}$ の順に良いと述べてい る.

私の成績では CL の感受性が94\%で一番高く，KM92 \%，Nf $78 \%$ と 3 者に対する感受性が群を抜いて良く， 1964 ・65年のそれ沉) と比較すると 3 者とも感受性率の上 昇をみている。

ブドウ球菌ではKM，に対する感受性が最高で $80 \%$ ，次

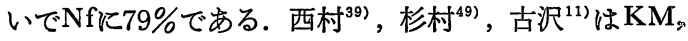
CP の順に良い感受性を示したと述べ，加藤 ${ }^{18)}$ は EM, $\mathrm{KM}$ 飞感受性が高く, 次いで CP, TC であると云い, 大井 ${ }^{43}$ は KM, EM の順であるとし, 稲田 ${ }^{16)}$ は $\mathrm{CL}>$ $\mathrm{KM}>\mathrm{CP}>\mathrm{TC}$ と述べている。また高井 ${ }^{50)}$ は1962〜1964 年の 3 年間には $\mathrm{KM}$ 耐性株の出現が 0 であつたと報告 している.今回の成績を1964・65年の成績と比較すると KMには感受性が76\%から80\%と上昇して拈り，KMは 現在な特最も有効な薬剤と云うことが出来る.

変形菌について Melnick ${ }^{33)}$ は CP, SM, KM の順に 感受性が高いと述べているが，わが国の報告では一様に KMが最高となつている。すなわち稲田 ${ }^{16)}$, 西村 ${ }^{39)}$ ，杉 村 ${ }^{49)}$ ，河田 ${ }^{20)}$ は $\mathrm{KM}$ に最も感受性が高く，次いで $\mathrm{CP}$ であるとし, 加藤 ${ }^{18)}$, 久世 ${ }^{30)}$, 高井 ${ }^{50)}$, 大井 ${ }^{43)}$, 古沢 ${ }^{11)}$ も $\mathrm{KM}$ に最高の感受性を示すと報告している.

今回のシリーズでも1964・65年のそれと同様にやはり KM に最高の感受性を示し，CP に60\%，SM には $40 \%$ であつた。しかも年次的に KM に対する感受性菌はむ しろ増加して和り, 変形菌に対しても有用な薬剤である と云えよう.

緑膿菌についてみると西村 ${ }^{39}$ は $\mathrm{KM}=\mathrm{TC}$ に最も高い 感受性を示すが, 全般的に低いと報告している. 加藤 ${ }^{18)}$ は KM, CLに30一60\%の感受性を示すと云い, 稲田 ${ }^{16)}$, 杉村 ${ }^{49}$ ，高井 ${ }^{503}$ は CL 《対して最も良いと報告し，大 井 ${ }^{433}$ は $\mathrm{KM}$ に最高で TC, EM ミにわずかに感受性があ つたと述べている。私の成績では CL のみに高度感受 性を有し，TC，KM，SM，CP には低感受性を示したに 過ぎない。

4. 小括

1966年 1 月より 12 月までの 1 年間に九大泌尿器科外来 を受診した尿路感染症患者について細菌分離を行ない, これら分離菌の化学療法剤に対する感受性検査を施行す るとともに1959年度, 1961年度, 1954 ・65年度の成績と 比較検討した。 
1）検出された菌は 145 株で球菌37株（25.5\%）,桿菌 97株（66.8\%）であつた.

2）菌種別に見るとブドウ球菌16株 (11.1\%) 大腸菌 57 株 (39.3\%),変形菌10株, 緑膿菌 5 株が主であつた。

3）疾患別に見ると膀胱炎，腎盂腎炎之もに大腸菌が 多く見られ，次いでブドウ球菌であつた。変形菌，緑膿 菌はともに膀胱炎に多く見られた。

4）前回までの報告と比較すると大腸菌はやや増加， ブドウ球菌は減少, 変形菌, 緑膿菌は年次的に大きな変 動は見られなかつた。

5） 8 種化学療法剤に対する感受性検査を行なつた結 果, ブドウ球菌は $\mathrm{KM}>\mathrm{Nf}>\mathrm{CP}>\mathrm{SM} \geqq \mathrm{EM}>\mathrm{TC}>\mathrm{CL}$ $>\mathrm{PC} て ゙ ， \mathrm{EM}$ に対して年次的な低下が見られた。

6）大腸菌の感受性は $\mathrm{CL}>\mathrm{KM}>\mathrm{Nf}>50>\mathrm{CP}>\mathrm{TC}$ $>$ EM > SM > PC の順であつた。

7）変形菌の 感受性は $\mathrm{KM}>\mathrm{CP}>\mathrm{SM}>\mathrm{TC}>\mathrm{CL}=$ $\mathrm{EM}=\mathrm{Nf}$ であつたが前回と同様, $\mathrm{KM}, \mathrm{CP}$ 以外飞は40 \%以下の低い成績であつた。

8）緑膿菌は CL 以外には感受性を示さなかつた。

9）ブドウ球菌の 8 種薬剤に対する感受性は全体的に 年々低下して来ているが，SM, CP, KM, Nt と対して は前回より若干増加した。大腸菌にも低下が見られる が， CL，KM，Nf には前回より感受性率が増加した。 変形菌は $\mathrm{SM}, \mathrm{CP}, \mathrm{TC}, \mathrm{KM}, \mathrm{Nf}$ に対する感受性が増 加した。Nf に対する感受性は大腸菌, ブドウ球菌とも 増加した。

\section{III. 腎機能障害時の化学療法}

前章に述べたごとく，尿路感染症より分離される細菌 は多少とも年次的に变遷しつつあり, かつ化学療法剤 に対する感受性にもかなりの変化を来しつつある。従 つて 尿路感染症 の治療にあたつては再三尿中細菌の培 養。感受性検查を施行し，常に適切な薬剤を使用する必 要があるが。総体的にみて KM が有効である場合が最
も多い。例えば $\mathrm{KM}$ に対してブドウ球菌は $80 \%$ ，大腸 菌は $92 \%$, 变形菌は80\%と高い感受性を示し, 緑膿菌 を除くほとんどすべての尿路感染菌に対し有効で，臨床 効果の面でも他剤に比し優れた薬剤であることは疑いの 余地がない。しかしながら近年 KM の腎毒性 ${ }^{122241) 57\}}$ に関する注意が喚起され，特に腎機能障害例の多い尿路 感染症では軽視出来ない問題となつて来た．そこで私は まず腎機能障害者に対し過去に㧊いて如何なる化学潦法 剤が使われて来たかを調査しそのような場合化学療法 剤がどのような動態を示すか，また実験的障害腎に対す る影響が如何なるものであるかを追究し，かかる腎機能 障害時の化学療法に関する対策について考えてみたので 以下述べてみる。

1。臨床例に抢ける観察

1）腎機能障害例に扩ける化学潦法剂の使用状況

a) 観察対象

1962年より1966年までの 5 年間に九大泌尿器科に入院 した患者 1,428名を対象にした。

慢性腎障害の基準には意見 ${ }^{48}$ があるが，私は BUN 40 $\mathrm{mg} / \mathrm{dl}$ 以上, PSP 排泄試験15分值10\%以下, 120 分値50 \%以下を規準とし，それに IVP 像を加えて綜合的に判 定して52例を選び，化学療法剤の使用頻度を調查してみ た. 腎機能障害例は急激に腎機能が停止した急性腎不全 7 例と，しからざる慢性腎機能障害45例とに分け，使用 薬剤を単独使用と併用とに分類してそれぞれについて検 討してみた。

b) 成績

第 6 表のごとく急性腎不全 7 例に腎毒性 ${ }^{22)}$ ある KM が他剤との併用で 3 例に使われ, SM は単独使用, 併用が 怙の扮の 1 例である。次に慢性腎機能障害 45 例には KM 単独使用16例，併用18例で，急性。慢性を総計すると 37 例飞使用されている. SM は単独 7 例, 併用 5 例, 総計 14 例であり，CL ${ }^{58)}$ は単独使用 6 例，併用14例で総計 20

第 6 表 腎機能障害患者に使用された化学療法剤

\begin{tabular}{|c|c|c|c|c|c|c|c|c|c|c|c|c|}
\hline & & $\mathrm{KM}$ & $\mathrm{S} M$ & $\mathbb{C}$ L & P C系 & C P & T C采 & EM采 & C $\mathrm{E}$ 系 $\mathrm{R}$ & NA & $\mathrm{Nf}$ & $\mathrm{S}$ 剤 \\
\hline \multirow{3}{*}{$\begin{array}{c}\text { 急性腎不全 } \\
(7 \text { 例 })\end{array}$} & 単独使用 & & 1 & & & 3 & 1 & & & & & \\
\hline & 併 用 & 3 & 1 & & 1 & 1 & 3 & & & & & \\
\hline & 話 & 3 & 2 & & 1 & 4 & 4 & & & & & \\
\hline \multirow{4}{*}{$\begin{array}{c}\text { 慢性腎障害 } \\
(45 \text { 例 })\end{array}$} & 単独使用 & 16 & 7 & 6 & 4 & 14 & 15 & 7 & 3 & 1 & 3 & 5 \\
\hline & 併 & 18 & 5 & 14 & 6 & 25 & 17 & 16 & 16 & 4 & 3 & 8 \\
\hline & 計 & 34 & 12 & 20 & 10 & 39 & 32 & 23 & 19 & 5 & 6 & 13 \\
\hline & 総 & 37 & 14 & 20 & 11 & 43 & 36 & 23 & 19 & 5 & 6 & 13 \\
\hline
\end{tabular}


例となつている．各種抗生剤の使用頻度の総計順位を見 るとKM 2 位, CL 5 位, SM 7 位となつている。

c) 小括

以上のごとく九大泌尿器科で使用された抗生剂をまと めてみたが，Kleeman ${ }^{22)}, \mathrm{Wright}^{58)}$ が腎毒性ありと云 丂 KM, CL， SM が相当な頻度て使用されている.こ れは感受性検査の結果がある程度関与しているとも考党 られるが，術後急性腎不全 7 例に対し，KM 3 例，SM 2 例が使用されており，やむを得ない事情があつたと云 え，腎庇護の面からさらに慎重な配慮が必要であつたと 反省している.な和艺の予後は死亡 5 例, 不明 2 例とな つている。

慢性腎機能障害に対しては KM が34例，CL 20例， SM は14例に投与されているが，そのために重篤な腎障 害を来したと思われる例はなかつた。 しかし結石を合併 した馬蹄鉄腎に腎切石術，狭部離断術を施行し重篤な術 後感染症を来した例に SM を長期間投与して, 完全襲 となつた 1 例をみている。

いずれにしても過去における私共の経験では腎毒性あ りとされている幾つかの化学療法剤が腎機能障害例に対 乙て応用されていることは，これらが依然尿路感染症の 治療に重要な役割を有することを意味しており, 腎機能 障害時に和ける化学療法の困難性を如実にあらわしてい る.

\section{2）腎機能障害例における化学療法剂の動態}

投与された薬剤の排泄が腎を介して行なわれるるので あれば，腎機能低下時には当然排泄が遅延するものと考 えられる。そこで私は腎より排泄される $\mathrm{KM}^{4) 5)}$ を用い て健常腎者の排泄動態抽よび腎機能障害患者における排 泄動態について検討し，併せて腎不全例に投与した KM が血液透析によつて如何に変化するかを検討してみた。

a ）検査方法扣よび対象

観察対象として入院患者中より健常腎者 2 名, 腎機能 不全患者 2 名を選び，それぞれ $\mathrm{KM} 1 \mathrm{~g}$ を筋注して経 時的に血中濃度を測定した。な拈中濃度は次項に述べ るごとき，全血デイスクを用いる B. subtilis PCI 219 薄層平板法によつて測定した。

b ) 成績

\section{i ）腎機能正常例}

第 7 図のごとく健常腎者 2 名の KM $1 \mathrm{~g}$ 筋注後の血中 動態は 1 時間でそれぞれ $23 \mathrm{mcg} / \mathrm{ml}, 19 \mathrm{mcg} / \mathrm{ml}$ の最高値 を示し，以後漸減して 3 時間値 $15 \mathrm{mcg} / \mathrm{ml}, 8 \mathrm{mcg} / \mathrm{ml}$, 5 時間值 $10 \mathrm{mcg} / \mathrm{ml} ， 4 \mathrm{mcg} / \mathrm{ml}$ を示していずれも10時
第 7 図. KM $1 \mathrm{~g}$, 筋注. 血中濃度（健常腎）

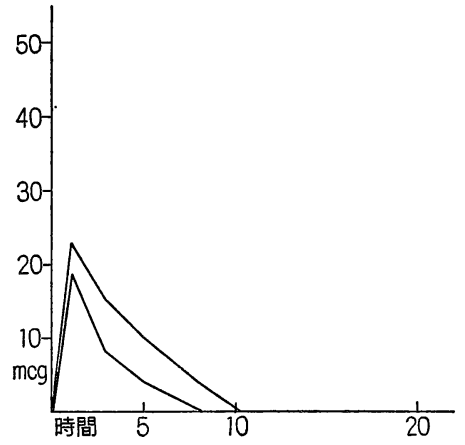

間，8時間で完全に排泄されている。

ii ）腎機能不全例

第 8 図は慢性腎炎末期の患者で，人工腎臟あるいは腹 膜潅流を間歇的に行なつている症例であるが，KM血中 濃度測定時の状態は尿量 0, BUN $122 \mathrm{mg} / \mathrm{dl}$, 血清クレア チン18.4mg/dlであつた．KM $1 \mathrm{~g}$ 筋注後の血中濃度は血 液透析を行なつていない状態では，最高值が $45 \mathrm{mcg} / \mathrm{ml}$ で36時間後にもなお33mcg/ml の高濃度を示している.

第 9 図の例は右単腎・腎杯皮膚庫形成, 腎感染の患者 で KM 血中濃度測定時の検査成績は BUN $45.7 \mathrm{mg} / \mathrm{dl}$ ， 血清クレアチン $5.6 \mathrm{mg} / \mathrm{dl}, \mathrm{PSP} 15$ 分值 0\%，120分値 9.6

第 8 図. 腎不全. $\mathrm{KM} 1 \mathrm{~g}$ 筋注. 血中濃度

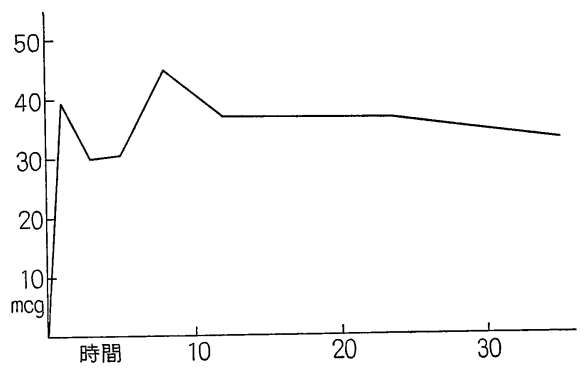

第 9 図. 腎不全. KM $1 \mathrm{~g}$ 筋注. 血中濃度

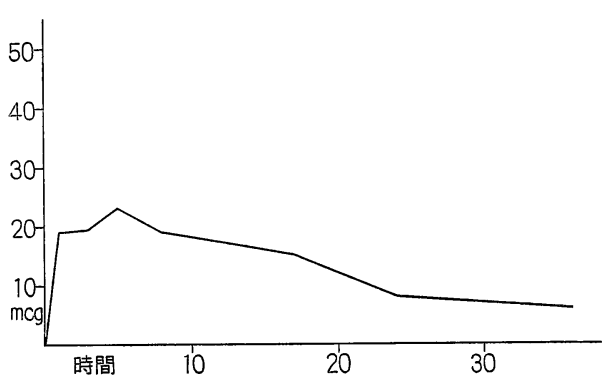


$\%$, 尿量 $1,450 \mathrm{ml}$ であるが, $\mathrm{KM} 1 \mathrm{~g}$ 筋注後の血中濃 度は最高值 $23 \mathrm{mcg} / \mathrm{ml}$ で，36時間後飞も $6 \mathrm{mcg} / \mathrm{ml}$ の血 中濃度が保たれている。第 1 例のごとき無尿例では, 36 時間程度では注とんど血中濃度の低下をみず, 第 2 例で は健常腎者に対して 4 〜 倍程度の排泄遅延を示してい る。

iii）血液透析による変動

血液透析時に KM の血中濃度がいかに変化するかを Permanent A-V (Arterio-Venous) shant を前腕に作 製した慢性腎炎末期の患者についてみた。

使用装置は Kolf 型 twin coil の人工腎臟で透析面積 は19,000sqcm である。透析の条件は透析液電解質 287 $\mathrm{mEq} / 1$, 滲透圧 $312 \mathrm{Osm} / \mathrm{l}, \mathrm{pH} 7.4$ 。透析液流量 $200 \mathrm{ml} /$ sec で 3 時間每に液を交換した. 透析中には $\mathrm{O}_{2} 90 \%$ ， $\mathrm{CO}_{2} 10 \%$ 液中に流した。結果は第 7 表のごとく $\mathrm{KM}$ $1.0 \mathrm{~g}$ 筋注 1 時間後に血中濃度は $120 \mathrm{mcg} / \mathrm{ml} ， 4$ 時間 後に $94 \mathrm{mcg} / \mathrm{ml}$ で透析率は $22 \% ， 0.5 \mathrm{~g}$ 筋注では 1 時間 後 $86 \mathrm{mcg} / \mathrm{ml}, 4$ 時間後 $52 \mathrm{mcg} / \mathrm{ml}$ で透析率 $39 \%, 0.25 \mathrm{~g}$ 筋注では 1 時間後 $54 \mathrm{mcg} / \mathrm{ml}, 4$ 時間後 $48 \mathrm{mcg} / \mathrm{ml}$ で透析 率11.1\%であつた.

第 7 表 人工腎による KM除去

\begin{tabular}{|c|c|c|c|}
\hline 筋注 & $\begin{array}{l}\text { 人工腎開始前 } \\
\text { (筋注 } 1 \text { 時 } \\
\text { 間後) }\end{array}$ & $\begin{array}{c}\text { 人工腎開始 } \\
4 \text { 時間後 }\end{array}$ & 除去率 \\
\hline $1.0 \mathrm{~g}$ & $120 \mathrm{mcg} / \mathrm{ml}$ & $94 \mathrm{mcg} / \mathrm{ml}$ & $22 \%$ \\
\hline $0.5 \mathrm{~g}$ & 86 II & $52 " 1$ & $39 \%$ \\
\hline $0.25 \mathrm{~g}$ & $54 \mathrm{II}$ & $48 \mathrm{II}$ & $11.1 \%$ \\
\hline
\end{tabular}

c) 小括

健常腎者にKM $1.0 \mathrm{~g}$ を筋注した場合の血中濃度の推 移について述べた報告は多く, Kunin ${ }^{27)}$ は血中half life を約 4 時間と述べ，Fingold ${ }^{9)}$ ，足立 ${ }^{2)}$ ，加藤 ${ }^{19)}$ ，金沢 ${ }^{17)}$ は潘とんどが12時間以内に排泄されると報告し，北本 ${ }^{21}$ は6 時間で大部分が排泄されたとしている。私の例では 8 -10時間で完全に排泄され，従来の報告とほぼ同様の 結果を示した。

腎機能障害例に括ける KM の血中濃度の動態につ いてもすでに多くの報告があり, Kunin ${ }^{28)}, \mathrm{Ory}^{44)}$, 足 立 $^{2)}$ ，加藤 ${ }^{19)}$ らは障害の程度によつて差があるが，24一 72 時間後の血中濃度の低下は非常に少ないと報告してい る。私の例では無尿患者の血中濃度は36時間後でもほと んど低下が認められず，中等度腎機能障害患者でも36時
間後になお血中 KM が検出されている.

血液透析時の KM の血中動態については, Greenberg $^{12)}$ ，加藤 ${ }^{19)}$ が述べたごとく, 私の例でも $1 \mathrm{~g}$ 筋注, 4 時間透析で $22 \% ， 0.5 \%$ 筋注 4 時間透析で $11.1 \%$ と動 摇はあるが，かなり透析によつて除去出来ることを示し ている。

2. Kanamycin の腎毒性と腎機能障害時に和ける影 響についての実験的研究

1） $\mathrm{KM}$ 血中蓄積簡易判定法の検討

KM の腎毒性および害験的に作製せる腎機能障害に 対する $\mathrm{KM}$ の影響を追究するためには， $\mathrm{KM}$ の血中 濃度を測定して扔く必要があるが，小動物では従来の測 定法のごとく充分な量の血液を再三採取することは困難 で，特に腎機能障害時には全身状態に悪影響を及ぼす危 険も大である。私は小量の血液で再三検查可能な方法と して，全血ディクスを用いる簡易法を検討してみたので 以下これについて述べてみる。

a ）実験方法

円形ディスクは東洋滤紙製径 $7 \mathrm{~mm}$ ○のを用い, 耳静 脈を注射針で穿刺して得られた血液をこれにしみ込ませ て血液ディクスとした．次にあらかじめ標準ペトリ血に 作製した厚さ $3 ー 4 \mathrm{~mm}$ のハートインフニージョン寒天平 板培地飞 Staphylococcus aureus 209P (九大細菌学教 室保存標準株) $10^{3}-10^{4} / \mathrm{cm}^{2}$ 程度に均等に表面塗沫し たのち，さきの血液ディスクをのせ，4時間冷所保存， $37^{\circ} \mathrm{C} 16$ 一2 0 時間培養してその阻止円を測定した。な和全 血デイスクと血清ディスク抢よび Cup plate 法とディ スク法 ${ }^{52)}$ の比較実験には B. subtilis PCI 219 胞子粉末 (武田薬品提供) をハートインフユージョン寒天培地に 混入し，これを薄層平板培地として前述の方式と同様に 測定した。

b ）実験成績

i ) 全血デイスクの重量

デイスクにしみ込む血液量の差によつて阻止円の直径 が変動することが考觉られるので，一定条件で作製した 血液デイスクを at random 飞重量測定を行なつてみ た。そ結果ディスク重量は12.1mg士0.1mgで一定して 特り，血液ディスクは $36.5 \mathrm{mg} \pm 1.3 \mathrm{mg}$ でデイスクにしみ 込む血液の量にはほとんど差がないことがわかつた。

ii ) KM 標準濃度とデイスク阻止円との関係

$10,20,25,50,75,100 \mathrm{mcg} / \mathrm{ml}$ の KM (KM 標 準濃度作製には明治製菓 $\mathrm{K} . \mathrm{K}$ 提供の KDX 28，707mg 力価のものを使用) を含むデイスクについて阻止円の直 
第10図．KM．ブドウ球菌 $209 \mathrm{P}$ 株 表面塗洙濾紙法。

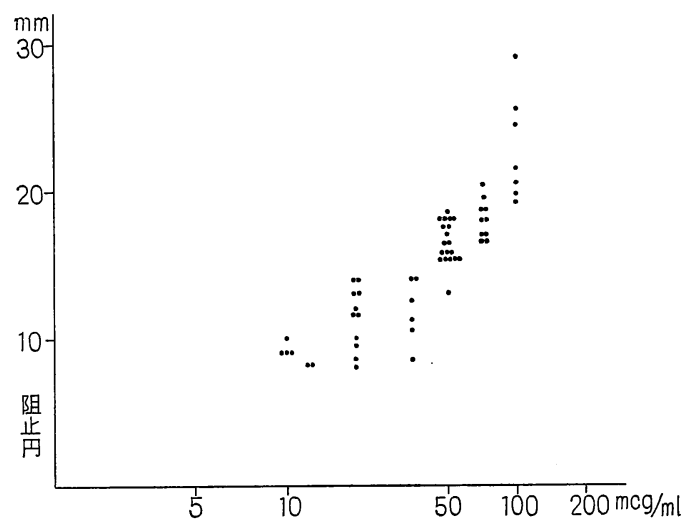

径を測定してみると，第10四のごとく多少のバラつきは あるが，ほぼ濃度に比例して阻止円が大きくなる傾向を 示して拉り，少くとも $\mathrm{KM} 10 \mathrm{mcg} / \mathrm{ml}$ 以上に蓄積した 場合の定性的判定には充分使用出来ることを知つた。

iii）全血と血清の比較

全血デイスクと血清ディスクによる差を健康家鬼に

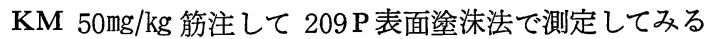
と, 第11図のごとく両者とも時間的推移にほとんど差が なく，5時間後には阻止円を生じなくなつている。

第11図. 健常腎家鬼 KM50mg/kgブドウ球菌 表面塗洙法

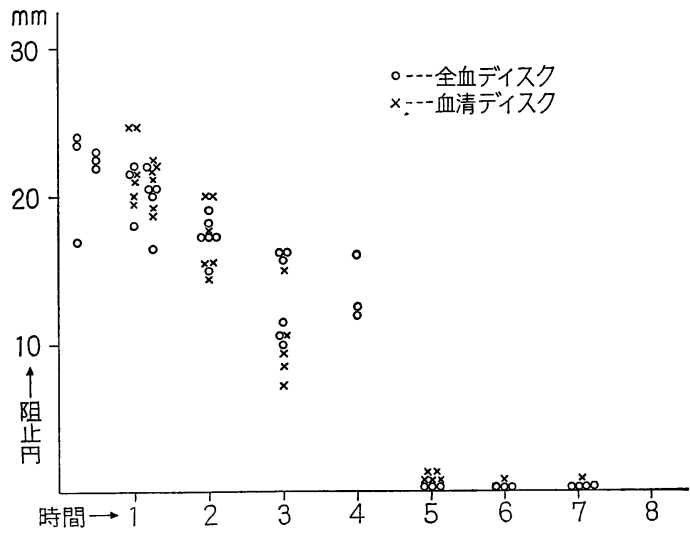

次に PCI 219薄層平板法で KM200mg投与後の状態を 比較すると，第12図のごとく全血がやや低值を示すが， 検出の鋭敏度には両者の間に大きな差はみられなかつ た。

iv) Cup plate 法とデイスク法との比較
第12図. 腎機能正常家鬼（2.4kg）KM 200mg投与

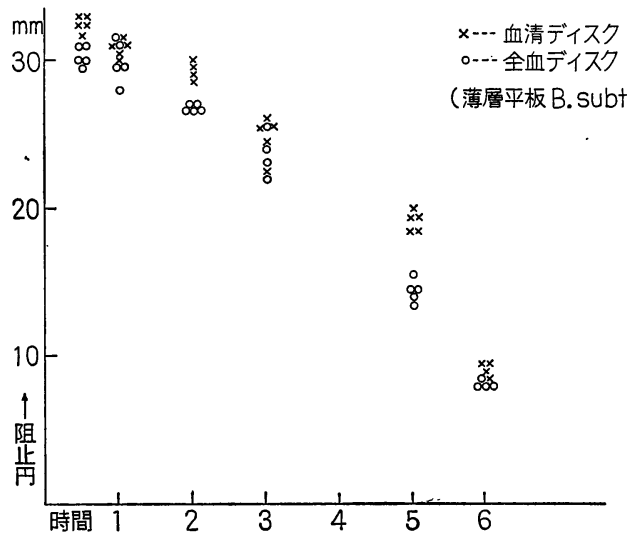

従来より抗生剤の体液濃度測定に常用され, 精度も高 いと云われている Cup plate 法と今回 のディスク法を 比較してみると, 前者は第13図, 後者は第14図のごとき 結果を示し, Cup plate 法の方が感度も良く, かつバ ラつきも少ない.しかしデイスク法は細かな数值を定量 的に測定する意味では多少難点があるが，KMが蓄積し ているか否かを定性的に知るためには充分目的を達し得 ることがわかつた

c ) 小括

以上のことから $\mathrm{KM}$ 血中濃度を定量的に測定するた めには Cup plate 法にて B. subtilis PCI 219薄層平板 法が必要であるが，本実験のごとく KM の血中蓄積状 態を簡単に把握する目的には全血デイスクによる $209 \mathrm{P}$ 表面塗洙法でも充分であり，小量の血液で簡単に推測出

第13図. KM. 検定 Cup plate 法 （薄層平板 B. subtilis）

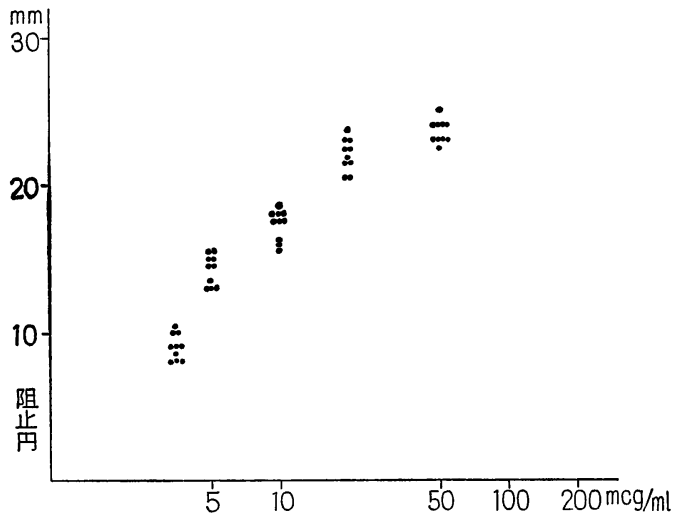


第14図。KM検定円滤紙法（薄層平板）

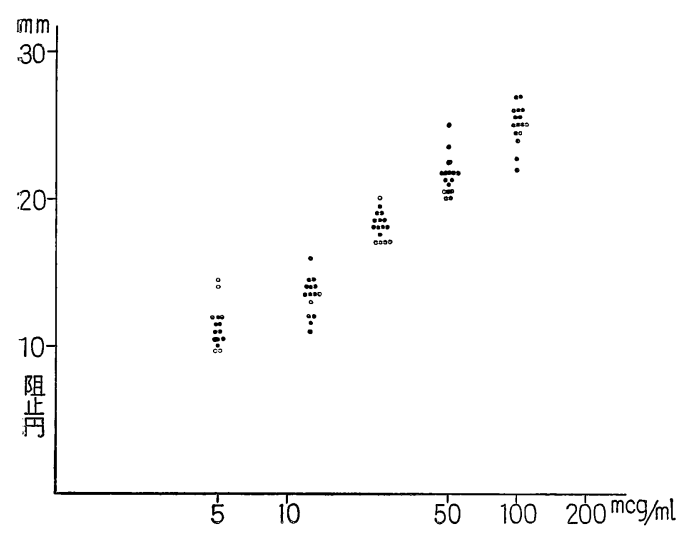

来る利点があるので, 以下の実験には専ら本法を用いる ことにした。

1） KM の腎毒性と障害腎に対する影響についての害 験

a ) 実験方法

i ）実験動物 体重 $3 \mathrm{~kg}$ 前後の雄家鬼を用い，一定期 間飼育して全身状態に異常がないことを確認したら兄 実験に供した。飼料は主としてオリェンタル固型飼料 RC 5 を用い，適宜领料水，野菜類を補給した。

ii）腎障害の作製 まず左腎を摘出し，次いで右尿管 を右腎下極より約 $2 \sim 3 \mathrm{~cm}$ の部位で狭窄した。狭窄の作 製には直径 $1.3 \mathrm{~mm}$ の輸血針を尿管に平行にあて，これを 尿管と共に 3 号絹糸で結紮した後，輸血針を引き抜く方 法をとつた（第15図）。

第15図. 実験群作製法

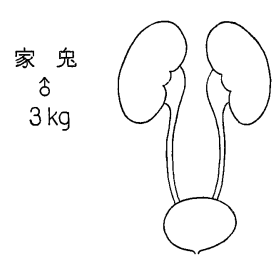

$\mathrm{KM} 50 \mathrm{mg} / \mathrm{kg} \quad A$ $\mathrm{KM} 300 \mathrm{mg} / \mathrm{kg} \quad \mathrm{B}$

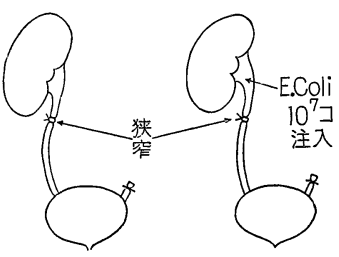

C D
E

F
なお一部の例には結紮個所の上部より, E. coli B (九 大細菌学教室保存株）を $10^{5} \sim 10^{7}$ こ腎孟内に注入した。

iii) 実験の進め方 家鬼に各種の準備操作を加えた後 7〜35日経過してから実験を開始した。な报 E。coli 注 入群では実験開始前に尿中細菌定量培養にて感染が若起
されていることを確認したらえ実験を進めた。

まず KM $1 \mathrm{~g}$ を蒸留水 $4.5 \mathrm{ml}$ を溶解し，1 日 1 回定 刻に大腿二頭筋内に 20 日間連続筋注したが，投与量とし て $50 \mathrm{mg} / \mathrm{kg} / \mathrm{day}$ の小量投与群と $300 \mathrm{mg} / \mathrm{kg} /$ day の大量 投与群に分けた. 実験群は第 8 表のごとく $\mathrm{A}, \mathrm{B}, \mathrm{C}, \mathrm{D}, \mathrm{E}, \mathrm{F}$ の 6 群に分け，それぞれ $3 〜 5$ 羽を使用した。

第 8 表 実験群の分類

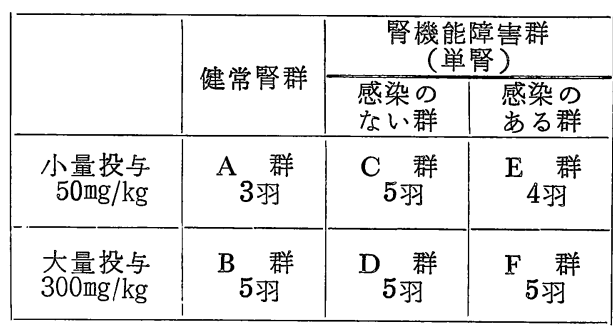

iv）検査の条件および項目各群ともに体重, 尿所 見, BUN, PSP15分値, KM血中蓄積傾向, 腎組織所見 をみ, 感染群ではさらに尿中細菌の定量培養 ${ }^{55)} 4-7$ 日間隔で行ない，その一部については屠殺あるいは剖検 時に腎組織内細菌の定量培養を行なつた。

1）尿所見：カテーテル尿を採取し，ヘマコンビスチ ックを用いて $\mathrm{pH}$, 潜血, 蛋白, 糖をみた。

2） BUN : ニニグラフを用いて 測定した。75mg/dl以 上ある場合には $10 \%$ アラビアゴム溶液で 2 倍まで稀釈し て測定した。

3） PSP 排泄試験：あらかじめ生理食塩水 $10 \mathrm{ml}$ を耳 静脈より注射して水分の負荷を行ない，10分後に PSP 注射液 $1 \mathrm{ml}$ を耳静脈より注射し，15分後の尿中排泄量 （\%）をカテーテル採尿でみた。採尿時には生理食塩水 で膀胱洗滌を行ない，採尿の䛊差が少なくなるようにつ とめた。

4） KM蓄積：さきに述べた血液ディスクー $209 \mathrm{P}$ 表 面塗洙法で注射24時間後の阻止円を測定した.

5）腎組織所見の検索: KM の20日連続筋注後, 生存 せるものについては耳静脈より空気注入で屠殺し，途中 衰弱せるものは可能な限り死を予知して死亡直前に同様 に屠殺し,型のごとく10\%ホルーリンで固定しっ・ランィ ン包埋により H.E 染色ならびにPAS染色で検索した。

6）尿中細菌定量培養：ハートインフュージョン寒天 平板培地で型のごとく行なつた。

7）腎組織中の細菌定量培養 : 腎の一部を無菌的に採 取後, ホモゲナイズして培養し一腎あたりの細菌数に換 算した。 
第16図. A群 $(50 \mathrm{mg} / \mathrm{kg} / \mathrm{day})$
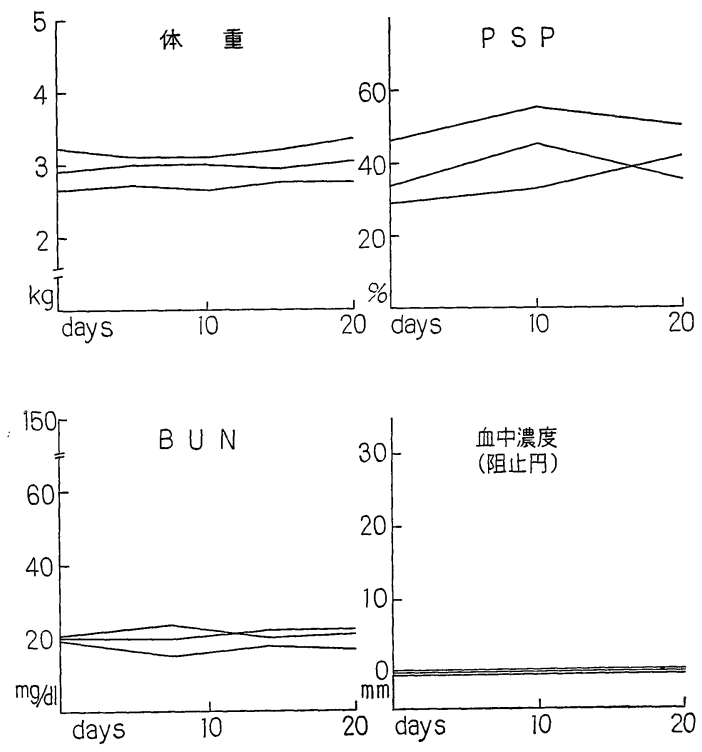

b ) 実験成績

i ) A 群 (50mg/kg/day，健常腎群 3 羽, 第16図)

体重：20日間に 5 回測定したが，その変動は $100 \mathrm{~g}$ 内 外でほとんど変化が認められない。

BUN：4 回測定したが，実験の前後で変動を認めな かつた.

PSP排泄試験 : やや変動を認めるが, 採尿時の誤差と 考えられる.

$\mathrm{KM}$ 蓄積 : 全例とも途中経過で蓄積は起らず，20回 筋注24時間後にも血中 $\mathrm{KM}$ は検出出来なかつた.

腎組織所見：写真 1，2（家鬼No. 28）のごとく糸球 体，尿細管上皮，間質に变化を認ぬない。

尿所見 : 投与終了後の尿検査で痕跡程度の尿蛋白を認 めたのみであつた。

ii ) B 群 (300mg/kg/day，健常腎群 5 羽，第17図)

体重 : 個体差はあるが食欲の低下とともに図のごとく 全例に体重減少がみられた。 4 羽が死亡し，時期はそれ ぞれ7日目，14日目，19日目であつた。20日間生存した ものは 1 羽のみであつた.

BUN : 全例ともに上昇したが，死亡例中の 1 羽は 42

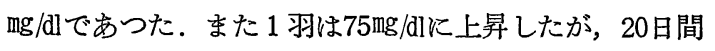
生存した。他の死亡した 3 羽はいずれも $150 \mathrm{mg} / \mathrm{dl}$ 以上と なつている。

PSP 排泄試験：注射開始前の価は23-56\%であるが, 全例ともに著しく低下した。 また尿量にかかわらず発色
第17図. B 群 $(300 \mathrm{mg} / \mathrm{kg} / \mathrm{day})$
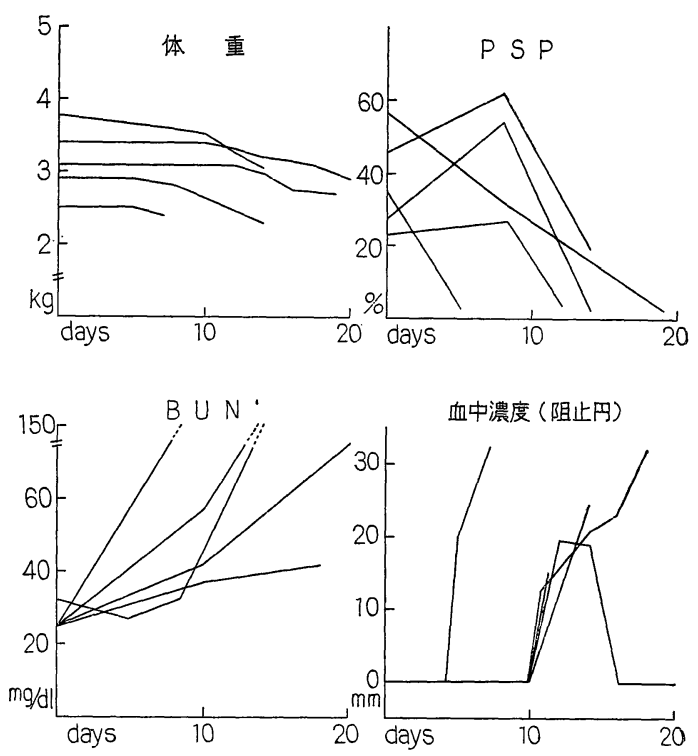

が低下した。

$\mathrm{KM}$ 蓄積： 7 日目死亡の 1 羽では 4 日目より急激に 蓄積が抽こり, 死亡時には23mmの阻止円を示し, 他は 12 日目に $15 \mathrm{~mm}, 14$ 日目に $24 \mathrm{~mm}, 18$ 日目に32mmの阻止円を示 して死亡した．20日生存例は12日，14日にそれぞれ 19 $\mathrm{mm}, 18 \mathrm{~mm}$ の阻止円を示したが，以後は蓄積を示さずに生 存した.

腎組織所見：屠殺例では近位尿細管の上皮に崩壊，水 尰様変性があり, 遠位尿細管に拡張, 中等度の硝子様円 柱がみられ，一部糸球体には係蹄の癒着が認められた。 死亡例では近位尿細管の上皮に同様の変化がみられた が，系球体は著変がなかつた．写真 3,4 (家鬼No. 44 右腎)では近位尿細管の崩萝, 一部に水腫様変性がみら れる。

尿所見： $\mathrm{pH}$ は全例ともアルカリ側より酸性側に傾い た. 尿蛋白は全例に出現し，30-100mg/alであつた. 血 尿は 4 羽にみられ，らち 3 羽は肉眼的に血尿を認めた。 さらに 3 羽に強度の尿糖をみた。

iii） C群 $(50 \mathrm{mg} / \mathrm{kg} / \mathrm{dl}$, 左腎摘- 右尿管狭窄 - 5 羽, 第18図)

体重： 1 羽が約 $500 \mathrm{~g}$ 減少したが, 他の 4 羽には著変 がなかつた。

BUN: KM 注射開始前は42-47mg/dlであり, 途中変 動はあつたが20日後には32-47mg/dlとなつて，KM に よる影響はないと考えられた。 
第18図.C 群 $(50 \mathrm{mg} / \mathrm{kg} /$ day $)$
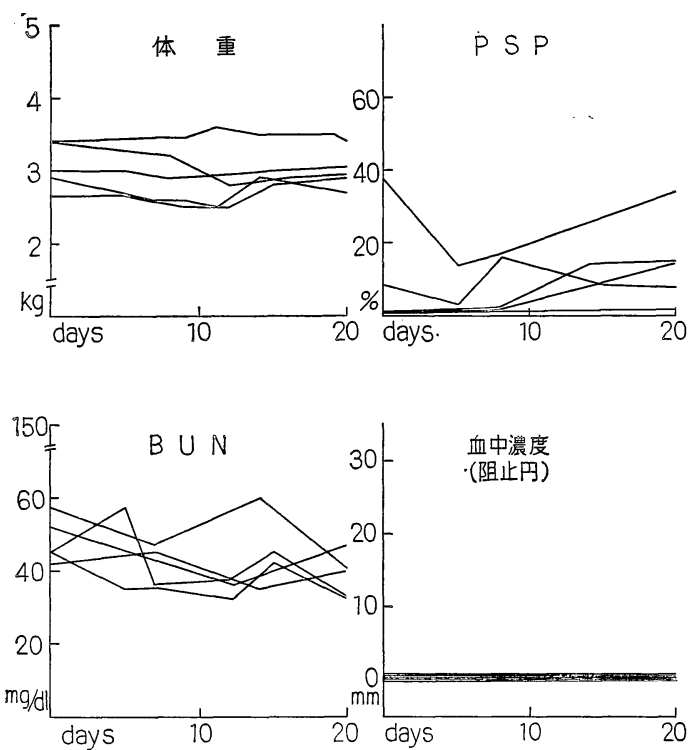

PSP 排泄試験：KM注射開始前は $0-37.5 \%$ であり， 終了後は 0-34\%であつてほとんど影響がなかつた。

$\mathrm{KM}$ 蓄積 : 全例ともに蓄積を示さなかつた。

腎組織所見：水腎症の所見が認められた。一部遠位尿 細管の強い拡張および一部の近位尿細管，糸球体に萎縮 がみられたが，尿管狭窄の影響と考学られる。写真 5 。

6 (家鬼No.67）では遠位尿細管の拡張が認められる.

尿所見：pHは全例とも変化なくアルカリ性であつた。

尿蛋白は全例に認められ痕跡ないし30mg/dlであつた。血 尿は 1 羽に軽度の潜血をみた．尿糖は全例ともに認めら れなかつた。

iv) D群 $(300 \mathrm{mg} / \mathrm{kg} / \mathrm{day}$ ，左腎摘。右尿管狭窄。5 羽，第19図）

体重：全例とも短期間に 500-600 g減少して，それ ぞれ $4 ， 5 ， 10 ， 11 ， 12$ ，目に死亡した。

BUN：KM 投与開始前は 32-50mg/dlであつたが，い ずれも死亡前には $75 \mathrm{mg} / \mathrm{dl} を こ え ~ 150 \mathrm{mg} / \mathrm{dl} に$ 近くなつてい る。

PSP排泄試験：KM 投与開始前は0ー17\%であたた が，全例 0-1\%以下となり死亡した。

$\mathrm{KM}$ 蓄積：5例とも蓄積を执こし，阻止円が増大し て，死亡前には22.5-30m となつた。

腎組織所見：遠位尿細管の多くは拡張し，硝子様円柱 がみられた。一部の近位尿細管上皮にはB 群と同様の崩 壊が認められたが, 糸球体には著変はなかつた。写真 7 ，
第19図. D 群 $(300 \mathrm{mg} / \mathrm{kg} /$ day $)$
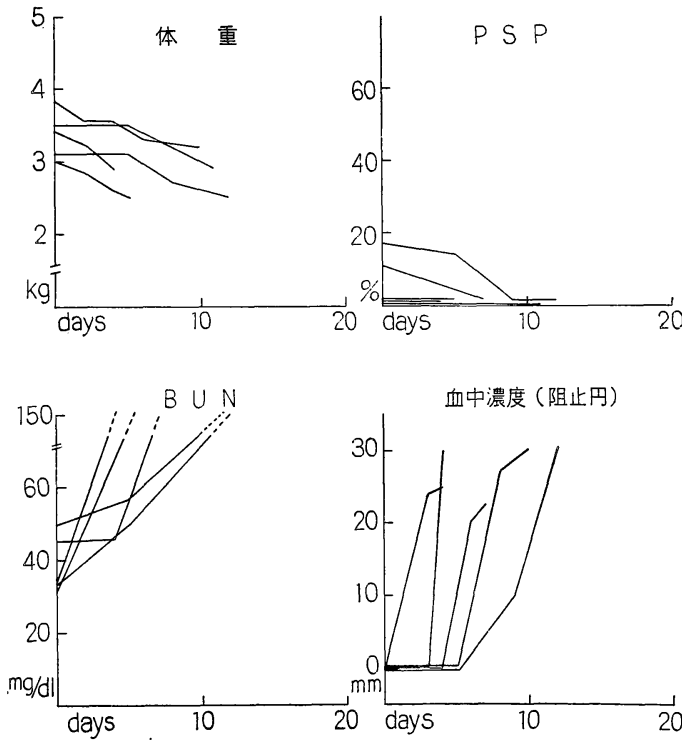

8（家鬼 No.69）では近位尿細管の崩壊，一部に水腫様 変性があり，遠位尿細管には細胞円柱がみられる。

尿所見 : 死亡経過が急であるために採尿した回数が少 ないが，尿蛋白は $100 \mathrm{mg} / \mathrm{d}$ 程度検出され，血尿も認めた。

v ) E 群 $(50 \mathrm{mg} / \mathrm{kg} / \mathrm{day}$ ，左腎摘・右尿管狭窄・腎感 染，4羽，第20図)

体重 : 20 回筋注の前後で 3 羽はほとんど不変であつた 第20図. $\mathrm{E}$ 群 $(50 \mathrm{mg} / \mathrm{kg} / \mathrm{day})$
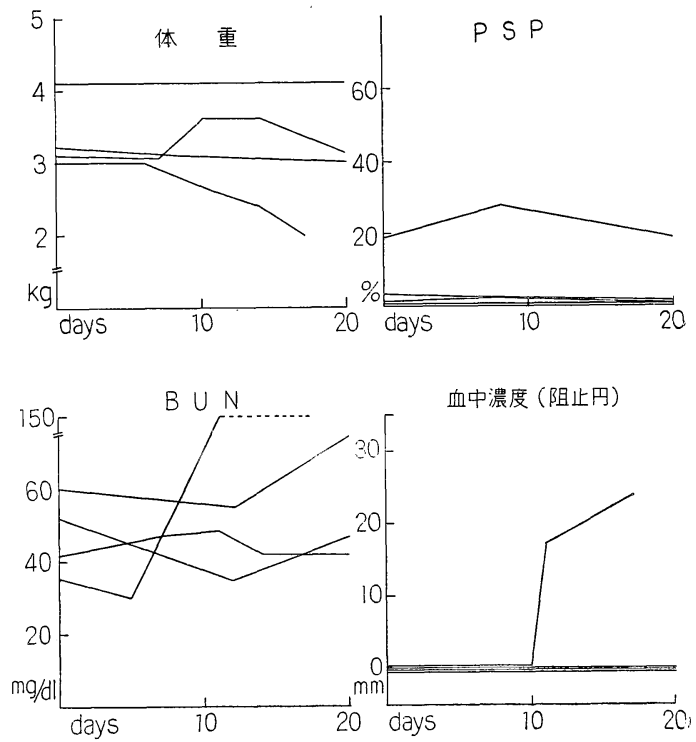
が，らち 1 羽は一時的に増加した. 1 羽が 7 月日頃より

減少しはじめ $1 \mathrm{~kg}$ 減少して17日目と死亡した。

BUN: KM 投与開始前には 35-60mg/dlであつたが,

1 羽が11日目から $150 \mathrm{mg} / \mathrm{dl}$ 上昇し，17日目に死亡し た. 生存した 3 羽中 2 羽はほとんど変化なく， 1 羽は60 $\mathrm{mg} / \mathrm{dl}$ より $75 \mathrm{mg} / \mathrm{dl}$ となつた.

PSP 排泄試験：KM 投与開始前は0ー19\%であつた が，19\%を示した 1 羽は20日後にも同值であつた。他は 0に近くほとんど不変であつた。

$\mathrm{KM}$ 蓄積 : 4 羽中 3 羽 は全く蓄積を来たさなかつた が，17日目に死亡した 1 羽は11日目 $17 \mathrm{~mm}$ ，死亡時 $24 \mathrm{~mm} の$ 阻止円がみられた。

腎組織所見：程度の差はあるが全例に腎孟腎炎の所見 がみられた，写真 9，10（家鬼 No. 91）では遠位尿細 管が拡張し一部に硝子円柱を認める. 近位尿細管には著 変はない.

死亡あるいは屠殺時の腎の細菌培養で 2 羽にそれぞ れ $168 \times 10^{2} /$ 腎， $36 \times 10^{2} /$ 腎 の大腸菌を検出したが， 7 日, 11 日で尿中細菌の消失をみた他の 2 羽は菌数 0 であ つた.

尿所見 : 全例に痕跡ないし30mg/dl程度の尿蛋白をみ, 死亡例では中等度の尿中潜血をも認めた。 $\mathrm{pH}$ は生存例で アルカリ侧 7-9, 死亡例は死亡前に酸性・6 となつた。

vi ） F 群 ( $300 \mathrm{mg} / \mathrm{kg} / \mathrm{day}$, 左腎摘・右尿管狭窄・腎 感染, 5 羽, 第21図)

体重: $\mathrm{KM}$ 投与開始前は $2.8-4.9 \mathrm{~kg}$ であつたが, :300- $900 \mathrm{~g}$ 急速に減少して 4 羽が死亡した. 20 日間生 存の 1 羽は変化がなかつた。

BUN：KM 投与開始前36-50mg/dlであつたが，4 羽 は急速に上昇し，それぞれ 6 日目・ $140 \mathrm{mg} / \mathrm{dl}, 10$ 日目・ $105 \mathrm{mg} / \mathrm{dl} ， 13$ 日目・150mg/dl，17日目・150mg/dlとなつ て死亡した.

PSP 排泄試験：はじめ 2.5一22.5\% であつたが 全例 ともほとんど発色しなくなり，生存した 1 羽は $22.5 \%$ よ り $0.1 \%$ 以下となつた.

$\mathrm{KM}$ 蓄積: 死亡した 4 羽はそれぞれ 6 日目 $26 \mathrm{~mm}, 10$ 日目 $23 \mathrm{~mm}$ ，12日目 $26 \mathrm{~mm} ， 17$ 日目 $32 \mathrm{~mm}$ の阻止丹を示して死 亡したが，生存例は蓄積を抏こさなかつた。6日目死亡 例は死亡時の尿の阻止円が $32 \mathrm{~mm}, 12$ 日目死亡例では当日 の尿の阻止円が $26 \mathrm{~mm}$ であつて, 蓄積のおこつた状態でも な敃かなり尿中に排泄されていた。

腎組織所見 : 近位尿細管に上皮の崩壊と水腫様変性が あり, 赤血球円柱もみられたが, 系球体にはほとんど変
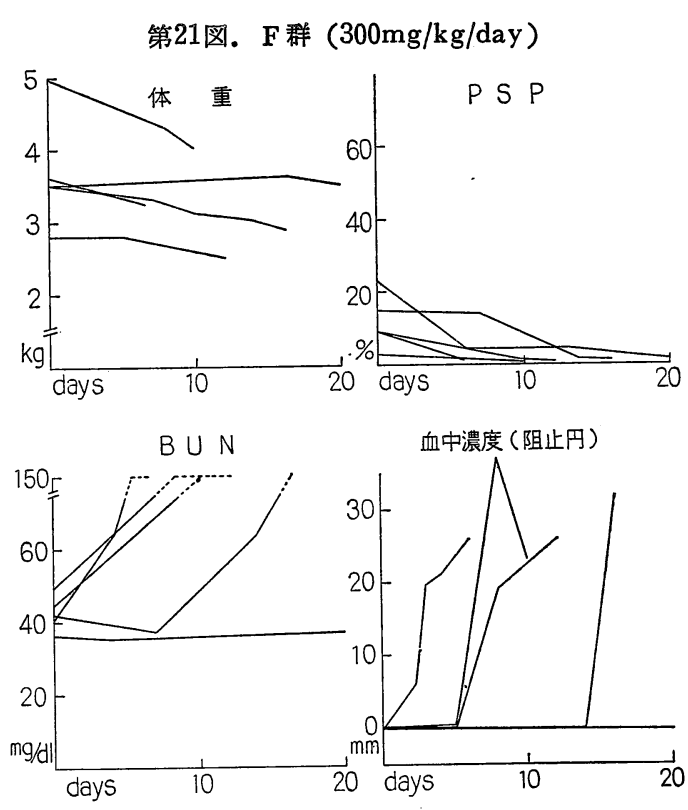

化がなかつた．遠位尿細管は軽度の拡張を示した。また 炎症所見は認められず，屠殺あるいは剖検時に行なつた 腎の細菌培養でも菌数は 0 であつた. その他 1 羽の腎孟 内に米粒大の結石 2 コを認めた。

写真11,12（家鬼 No. 60）では近位尿細管上皮の崩 壊, 水腫様変性が見られる。

尿所見：pH死亡例では酸性側に傾き，生存例ではほ とんど 9 亿固定していた．尿蛋白は30-100m//d であつ た. 血尿は中等度の潜血ないし肉眼的血尿をみた. カテ 一テル採尿による尿中細菌培養で検出された大腸菌は, 注射開始 1 週間前後で消失した。

vii） KM 連続筋注による死亡数

動物実験の成績を健常腎群と感染に関係なく腎機能障 害群に大別して, $50 \mathrm{mg} / \mathrm{kg} /$ day 群と $300 \mathrm{mg} / \mathrm{kg} /$ day 群 についてそれぞれ死亡数を具体的データのとれなかつた 例も含めて比較すると, 第22図のごとく健常腎群 (A,B 群) 飞 $50 \mathrm{mg} / \mathrm{kg} / \mathrm{day} 20$ 回連続筋注した場合の死亡数は 0 であるが， $300 \mathrm{mg} / \mathrm{kg} / \mathrm{day}$ になると 5 羽中 4 羽 ( 80 \%）が死亡した。

腎機能障害群 (C,D,E,F 群) そ50mg/kg/day を連続 筋注すると第 23 図のごとくに12羽中 3 羽 $(25 \%)$ が死亡し た. $300 \mathrm{mg} / \mathrm{kg} / \mathrm{day}$ では17羽中13羽 $(76.4 \%)$ が死亡 して, その時期は約半数が10日目前後であつた.

3）小括

a) 尿所見 
写真 1.A群（家鬼 No. 28) $100 \times$

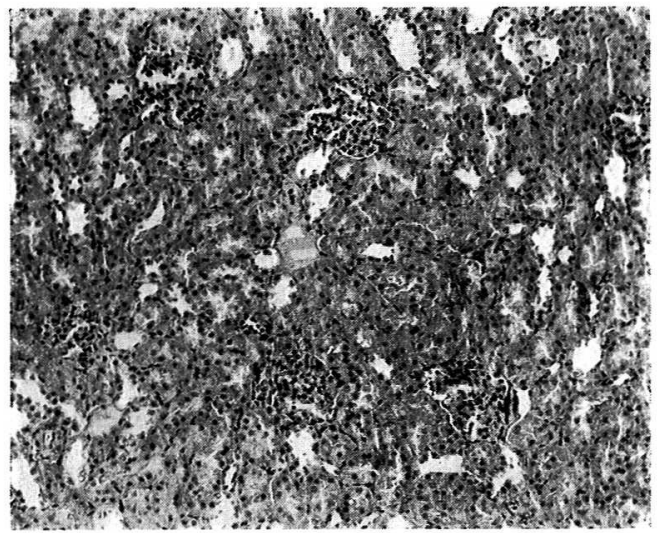

写真 3。B 群（家㭧 No. 44） $100 \times$

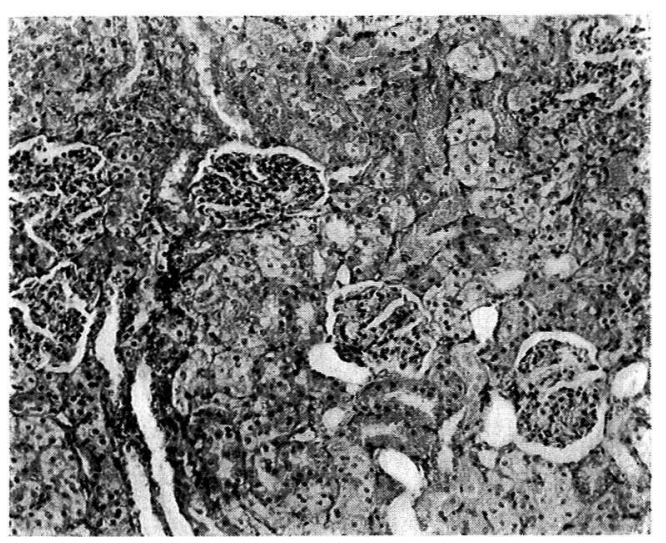

写真 5.C群（家鬼 No. 67） $100 \times$

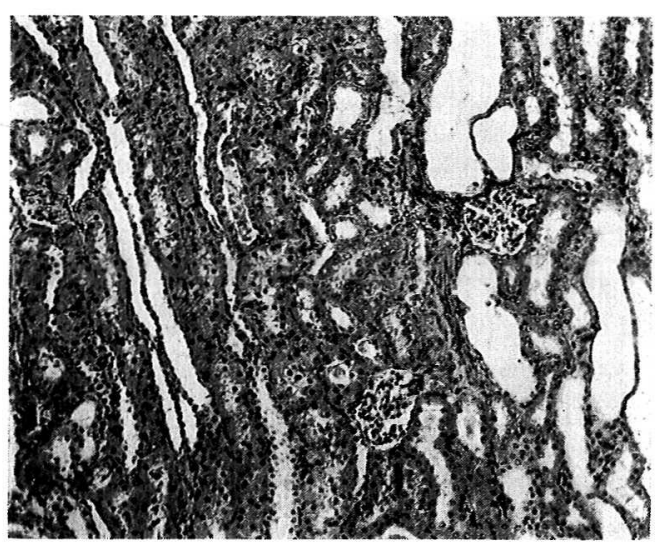

写真 2.A群（家鬼 No. 28） $210 \times$

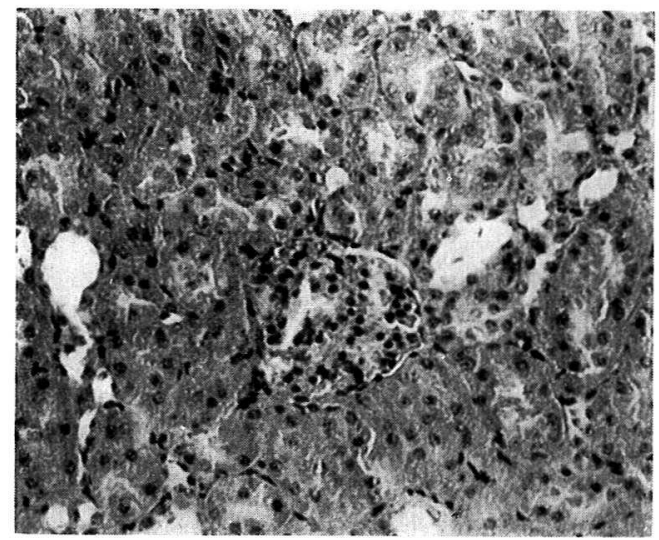

写真 4. B 群 (家鬼 No. 44) $210 \times$

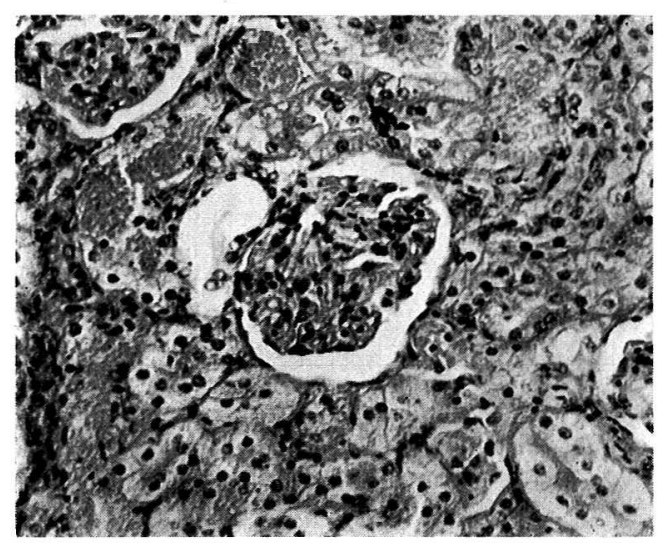

写真 6.C群（家鬼 No. 67） $210 \times$

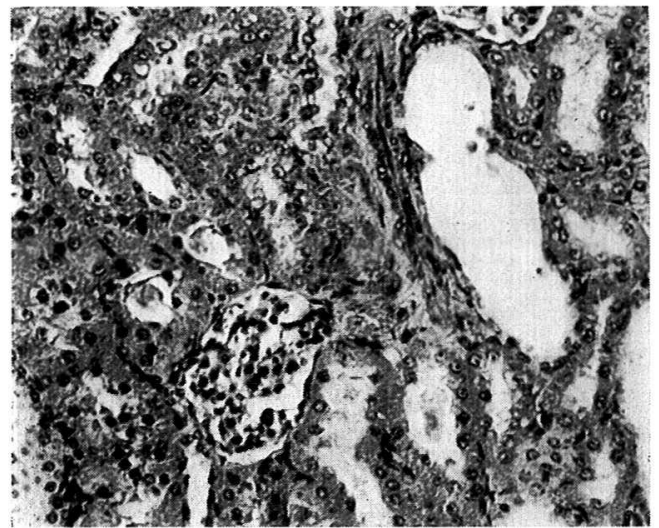


写真 7。D群（家鬼 No. 69） $100 \times$

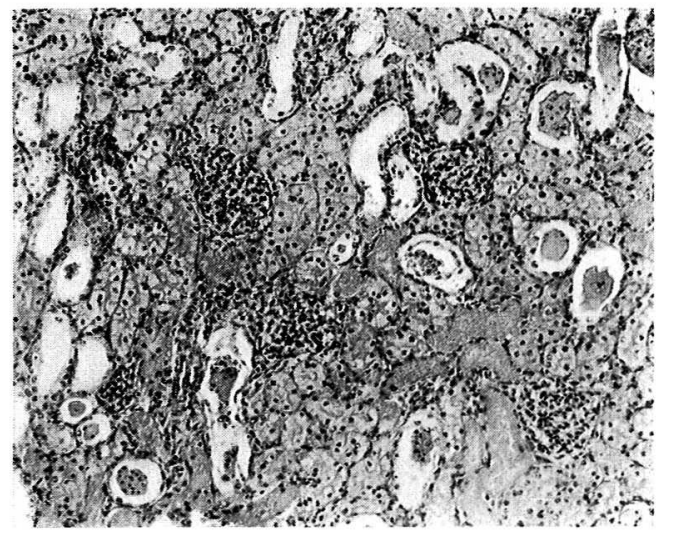

写真 9.E群（家鬼 No. 91） 100x

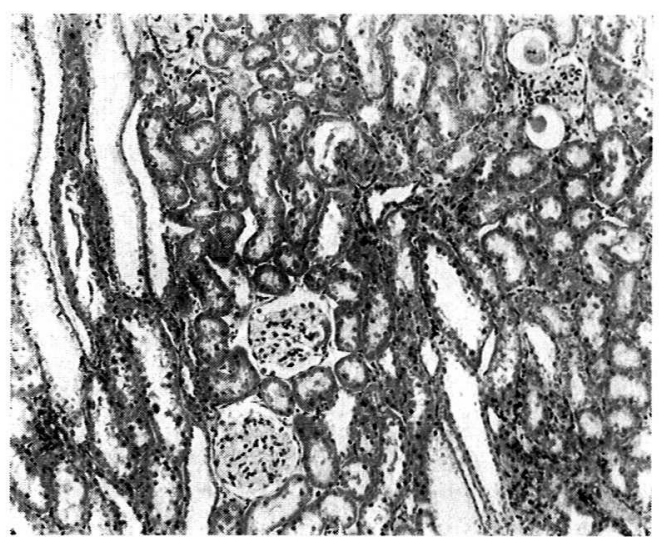

写真11。 F 群 (家鬼 No. 60) $100 \times$

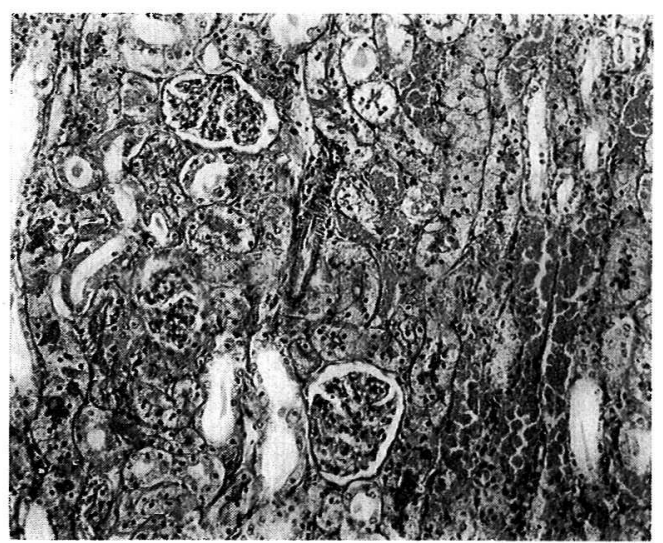

写真 8.D群 (家鬼 No. 69) $210 \times$

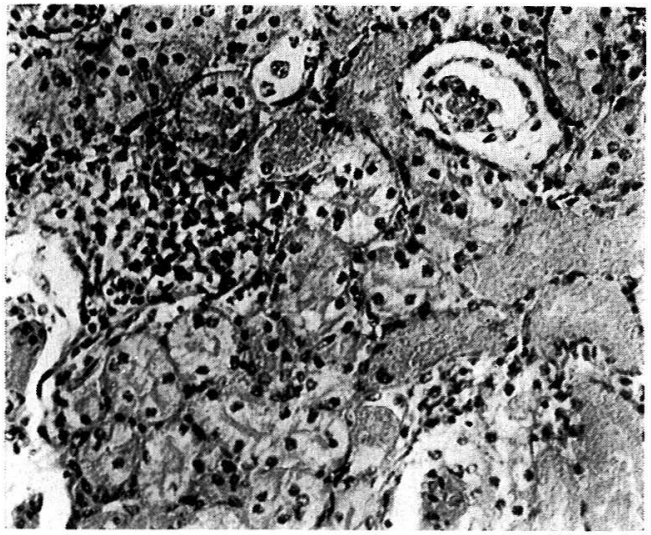

写真10. E 群（家鬼 No. 91） $210 \times$

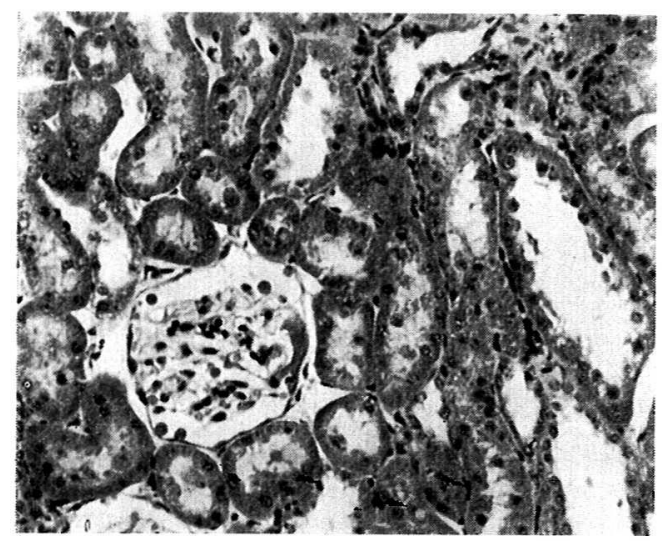

写真12. F 群（家息 No. 60） $210 \times$

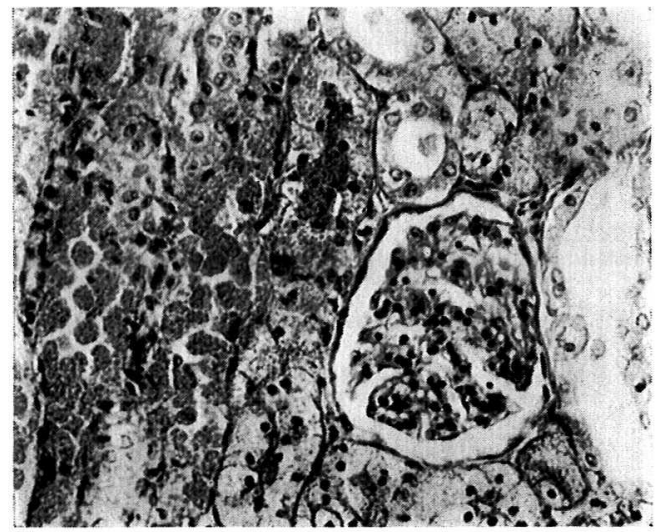


第22図．正常群死亡経過

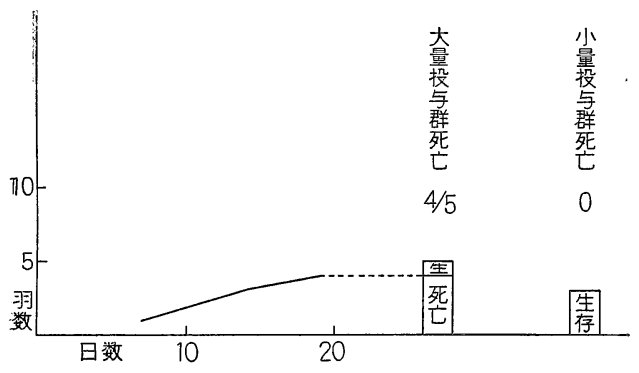

第23図. 腎機能不全群死亡経過

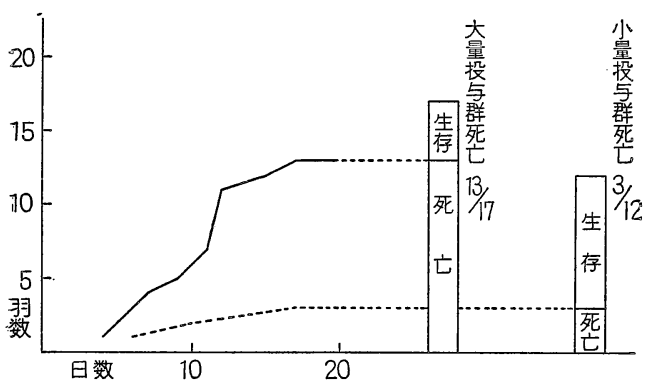

i ） $\mathrm{pH}$ : 生存例ではアルカリ側 8〜9 とあり, 死亡例 は死亡前に酸性側 $5 \sim 6$ 亿傾いた。

ii ）潜血： $50 \mathrm{mg} / \mathrm{kg} / \mathrm{day}$ の健常腎群は全例とも陰性 で, 同量の腎障害群では $2 / 9$ に軽ないし中等度みられた。 $300 \mathrm{mg} / \mathrm{kg} / \mathrm{day}$ では群に関係なく中等度の潜血ないし 肉眼的血尿をみた。

iii）尿蛋白：健常腎群, 腎障害群ともに $50 \mathrm{mg} / \mathrm{kg} / \mathrm{day}$ では痕跡ないし30mg/dl，300mg/kg/day では30〜 100 mig/dlを認めた。

iv）尿糖： $300 \mathrm{mg} / \mathrm{kg} /$ day で健常腎群に強度 2 例, 中等度 1 例をみ。腎障害群には中等度 3 例をみた。 $\mathrm{KM}$ 炕る腎障害では必発はしていない。50 $\mathrm{mg} / \mathrm{kg} /$ day で は全例陰性であつた。

b ) 体重 $: 50 \mathrm{mg} / \mathrm{kg} / \mathrm{day}$ では活とんど不変であり, $300 \mathrm{mg} / \mathrm{kg} /$ day では多くが急速に減少して死亡した.

c ) BUN : $50 \mathrm{mg} / \mathrm{kg} /$ dayではほとんど不変, $300 \mathrm{mg} /$ $\mathrm{kg} / \mathrm{day}$ では多くが上昇して死亡した。

d) PSP 排泄試験 $: 50 \mathrm{mg} / \mathrm{kg} / \mathrm{day}$ ではほとえと変化 なく，300mg $/ \mathrm{kg} / \mathrm{day}$ では低下して死亡した。

e ) $\mathrm{KM}$ 蓄積: $50 \mathrm{mg} / \mathrm{kg} / \mathrm{day}$ では蓄積をおこさず, $300 \mathrm{mg} / \mathrm{kg} / \mathrm{day}$ では蓄積して死亡した。

f）腎組織所見 : $50 \mathrm{mg} / \mathrm{kg} / \mathrm{day}$ ではほとんぞ KM に

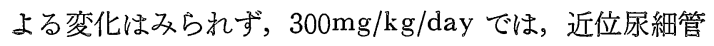

の上皮に核の消失, 胞体の崩壊, 水腫様変性などの変化 を認めたが，系球体には注とんど変化がなかつた。

g）以上の諸点を総合すると $\mathrm{KM}$ が腎に悪影響を及 ぼすのは，体内に異常に高い濃度で存在する場合に限ら れここれが腎を障害するか否かを見究めるためには KM の血中蓄積状沉を知ることがもつとも重要であるといら ことが出来る。

\section{3. 考察}

現在まで本邦で常用されて来た抗生剂の重篤な副作用 については PC による anaphylaxy shock ${ }^{7)}$, CP の骨 䯣抑制作用 ${ }^{32)}$ ，SM，KM による第 8 神経障害ならびに 腎毒性 ${ }^{22)}$ ，CL の腎毒性 ${ }^{58)}$ な゙が知られているが最近と くに抗生剤の腎毒性に着目した報告が増加している。

泌尿科領域において化学的療法の対象となるような症 例では程度の差はあれ腎機能の障害されたものが多く。 さらに起炎菌の薬剤感受性恰査を行なつてみると腎毒性 があると云わ机る薬剤のみが有效である場合も少なくな い。事実われわれの外来分離菌の統計でも年次的な変 遷はあるが，KM，CL に対する感受性は依然として高 い。

このことが実際の抗生剤の使用面にいかに投影され ているかを見ると，1962年～1966年の 入院患者の急性 腎不全例に KM 3 例, SM 1 例が投与され，慢性腎機能 障害45例には KM 34例，SM 12例，CL 20例が使用さ れている.このよらな投与例の全てが禁忌であるとは云 学ないが，少なくとも急性腎不全例への投与は透析療法 中以外は不適当であつたと云わねばなるまい。

このような抗生剂が投与された場合の血中動態を $\mathrm{KM}$ についてみると，腎機能正常例にKMＩｇを筋注した場 合, Kunin $5^{2(9) 17) 19221) 28)}$ が 6 時間から12時間で大部分 が排泄されると述べたごとく。私の例でも 8 時間〜10時 間で完全に排泄されている。

腎機能障害者に拈ける血中 KM の動態についてはす

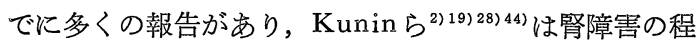
度によつて差があるが，24一72時間後でも血中濃度が高 く持続していると述べている．私の例でも無尿患者では 36時間後の測定で浪とんど血中濃度の低下は見られてい ない。さらに BUN $45.7 \mathrm{mg} /$ dll, 血清クレナチニン 5.6 $\mathrm{mg} / \mathrm{dl}$ の中等度腎障害患者では36時間後にもな和血中に KMが証明されている。

このような事実が，腎障害患者に KM の連続筋注を 行なつた場合, 排泄遅延のために蓄積をおこし，加藤 $ら^{199}$ も述べたごとく大量投与と同様な結果を招来し，さ らに腎障害を進行させるものと考穴られる。 
血液透析による血中 KM の除去 について, Greenberg ${ }^{12)}$ は $\mathrm{KM} 0.5 \mathrm{~g}$ 筋注後の腹膜潅流時における血中 濃度曲線より, 急速な初期相と緩徐な二次相があり, half lifeはそれぞれ 5 時間，48時間で平均除去率は 4.4 $\mathrm{mg} / \mathrm{hr}$, 腹膜クリアランスは $5.3 \mathrm{ml} / \mathrm{min}$, と報告してい る.また加藤ら ${ }^{199}$ は土工腎臓は 6 時間, 腹膜潅流では 12 時間の透析で血中濃度が半減するが，以後は潘とんど低 下しないと述べている。

私は同一例に $1.0 \mathrm{~g}, 0.5 \mathrm{~g}, 0.25 \mathrm{~g}$ 筋注して人工腎 による透析を行なつたが，筋注後 1 時間に対する透析 4 時間後の除去率はそれぞれ $22 \% ， 39 \% ， 11 \%$ であり，か なり良い除去率であつた。

動物実験では, KM の腎毒性について Kleeman ${ }^{22}$ は犬を用い，100mg/kgを40日〜 9 カ月使用してる腎障害 をおこさないが，100- 200mg/kgでは近位尿細管の拡張 および上皮の壞死をおこし，200 $\mathrm{mg} / \mathrm{kg}$ 以上になると BU $\mathrm{N}$ の上昇, 尿蛋白, 血尿を来し, 時に無尿となり, 組織 所見でも重篤な尿細管障害を来したと述べている.

野村 ${ }^{41)}$ は犬に 200- 400mg/kg を20日間連続筋注して 尿蛋白, BUNの増加を認め, 足立 ${ }^{1}$ は家鬼で $50 \mathrm{mg} / \mathrm{kg} 30$ 日 間では腎機能，腎組織所見に著変なく，200mg/kg 30日間 になると健腎には注とんど影響 しないが，障害腎では PSP排泄低下，BUN の上昇をみ，組織所見で近位尿細 管の拡張, 上皮の扁平化, 変性を来したと述べている.

私の実験では健常腎家兔に $50 \mathrm{mg} / \mathrm{kg}$ を20日間連続筋注 した場合，末期に極く軽微の蛋白尿を見たのみで，他の 検查項目には全く変化は見られなかつたが，300m/ $/ \mathrm{kg}$ 連続筋注すると体重減少, PSP 值の低下, BUN 上昇, $\mathrm{KM}$ の蓄積傾向が 著明におこり, $30-100 \mathrm{mg} / \mathrm{dl}$ 尿蛋 白, 血尿, 時に尿糖をみ，20日間生存した例も 途中死 亡例もともに腎組織所見で近位尿細管の上皮に 核の 消 失, 胞体の崩壊, 水腫様変性が見られたが, 系球体には ほとんど変化を認めなかつた。

腎機能障害群の $50 \mathrm{mg} / \mathrm{kg} 20$ 日連続筋注では体重, BUN, PSP 值ともに変化なく $\mathrm{KM}$ の蓄積も来さない。また 腎組織所見でも尿管狭窄の影響による遠位尿細管の拡張 以外は汪とんど変化を認めなかつた，尿所見では痕跡な いし30mg/d1の尿蛋白を認めた. この群の $300 \mathrm{mg} / \mathrm{kg}$ 連続筋 注では健常腎群の同量投与の場合と同様の変化を諸検査 で認めたが，経過が急であつた。

腎機能障害十感染群では $50 \mathrm{mg} / \mathrm{kg} / \mathrm{day}$ で 1 羽が死亡
乙, $300 \mathrm{mg} / \mathrm{kg} / \mathrm{day}$ と同様の変化を経過, 組織所見に示 した. 20 日連続筋注後に感染が治癒していない 2 例があ つたが，これは感染期間の長いものであつた。しかしな がら，腎組織検查では治癒したと考兄られた 2 例も含め て全例に腎孟腎炎の所見があり，上部尿路感染治療の困 難さを 考えさせた。 $300 \mathrm{mg} / \mathrm{kg}$ 連続筇注では体重減少， PSP 值低下, BUN 上昇, KM 蓄積が早期より抗こつ て多くは10日前後で死亡した. 腎組織所見では近位尿細 管の変性が強く, 赤血球円柱も認められたが糸球体には 変化がなかつた。この群で一般状態良好のまま20日生存 した 1 例があつたが，腎組織所見では一部の近位尿細管 上皮に死亡例と同様の変化が認められた。

以上の各群を通覧すると, 投与量の如何にかかわらず 死亡したものはすべて, 中等度の尿中潜血ないし肉眼的” 血尿, $30 \mathrm{mg} / \mathrm{dl} \sim 100 \mathrm{mg} / \mathrm{dl}$ 尿蛋白, 筋注 24 時間後の血中 飞 KM の証明, 体重減少, BUN 上昇, PSP 值の低下 をみている。

KMの腎毒性は人と動物によつて異なる ${ }^{22) 53)}$ と云われ ているので，以上の動物実験の成績を直ちに臨床的な問 題に直結出来ないかも知れないが， $\mathrm{KM}$ 投与時の尿中 潜血, 尿蛋白の $30 \mathrm{mg} / \mathrm{d} 1$ 以上の增加, 特に筋注 24 時間後の 血中 $\mathrm{KM}$ の残存は有力な指標になると考学られる. 少 くとも第 2 回以後の $\mathrm{KM}$ 筋注時に血中 $\mathrm{KM}$ が存在し なければ蓄積を怙こして腎障害を更に進行させる恐れは ないであろう．その意味において私の考案した全血デア スクによる209P 表面塗洙法は簡単にこれを推測し得て。 臨床的にも充分応用されて然るべき方法と考兄ている。

腎機能障害患者に腎毒性を有する抗生剤を投与する必 要が生じた場合，いか投与するかについて， Atuk ${ }^{32}$ はクレアチニンクリアランスが $2 \mathrm{ml} / \mathrm{min}$. 以下の高度の 腎障害では, KMの 1 回筋注で有效血中濃度が70〜 100 時間持続するので, 2 回以後は $3-4$ 日毎に少量を投与 すれば充分であるとし，Kunin ${ }^{26)}$ はさらに詳しく腎機 能障害の程度をクレアチニンクリアランスで分け, 10 $\mathrm{ml} / \mathrm{min}$. 以下であれば, 初回に常用量を投与し, 以後 $1 / 2$ 量を 3-4 日間隔, $10 \mathrm{ml} / \mathrm{min}$ 。以上では初回常用量, 2 回以後は $1 / 2$ 量を $1.5-2$ 日毎に投与し, 肝疾患を合併 する場合はさらに嗾密な投与計画が必要である.クレア チニンクリアランスが低くとも BUN あるいは血清クレ アチニンが正常範囲であれば健常人と同様に投与する。 感染症治療には最も效果の期待出来る薬剤を選択し，腎 毒性があつてもそれを避けるべきではないと述べてい る. 
私の考宇では上に引用した識者の投与計画は有用で且 つ大いに参考となり得るものであるが，先に述べたごと く $\mathrm{KM}$ ではそれの大量蓄積が腎障害を更に進行させる 結果となるので，重篤な症例に止む得ず投与しなければ ならない場合には，多少繁雑になるとは云光絶兄ず血中 濃度を観察して行くほどの慎重な配慮が望ましく，この 点で先の全血ディスク～ $209 \mathrm{P}$ 表面塗洙法は簡便で臨床 的に充分応用出来るものと考学る。

以上のごとき諸点を考慮した上で使用すれば腎障害患 者にも KM は充分使用にたえ得る薬剤であり，本剤の 原路感染症治療に和ける優秀性を考光る時，いたずらに これを回避する必要はないと云つてよい。

\section{IV. 総括ならびに結論}

1. 1966年に九大泌尿器科において経験した尿路感染 症患者より細菌分離を行ない，これらの化学療法剤に対 する感受性検査を施行し，1959年，1961年，1964～1965 年度のそれと比較検討して，その年次的变遷を観察した 結果，次のごとき成績が得られた。

1 1) 1966年に検出された菌は 145株で, 球菌37株(25.5 $\%)$,桿菌97株（66.8\%）であつた。菌種別には大腸菌57 株 $(39.3 \%)$,ブドウ球菌16株 (11.1\%), 变形菌 (10株), 緑膿菌（ 5 株）の順に多かつた。

2）1965年度までの成績と比較すると，大腸菌はやや 增加，ブドウ球菌は減少，変形菌，緑膿菌は年次的に大 きな変動は示さなかつた。

3)筑感受性検查の成績では，ブドウ球菌は KM, Nf, CP の順に感受性が高く, PC 感受性株の激減と EM の年次的な低下がみら机た。大腸菌はCL, KM, Nf, CP の順で，他には50\%以下を示し，变形菌は $\mathrm{KM}, \mathrm{CP}$ 以 外には低い成績であつた．緑膿菌は CL 以外には感受性 を示さなかつた。

4）感受性の年次的変遷をみると。ブドウ球菌，大腸 菌は全般的に低下しているが，KM，Nf の二者に対し ては感受性が高くなり，変形菌でる同様の傾向がみられ た。

5）以上のことから $\mathrm{KM}, \mathrm{Nf}$ は現段階に和ける尿路 感染治療剂として依然優れた薬剤であると云うことが出 来, 特に KM は切札的存在として臨床的にも捨て去る ことの出来ない有用な治療薬と云い得る。

2。1962年より1966年までの 5 年間に九大泌尿器科に 入院した52例の腎機能障害例に対し，いかなる化学療法 剂が使用されているかを調查した結果, 急性腎不全 7 例 中 $\mathrm{KM} 3$ 例, SM 2 例, 慢性機能障害例45例化 $\mathrm{KM}$
単独16例, 併用18例, SM 単独 7 例, 併用 5 例となつて いた。これら薬剤の使用によつて腎障害が重篤化した事 実は明らかに出来なかつたが，かかる腎毒性ありとされ る化学療法剈を投与せざるを得なかつたところに尿路感 染症治療の困難性がらかがわれ，特に腎機能障害時の化 学療法剤の使用規準を確立する必要があることを痛感せ しめられた。

3。腎機能障害例に和仔る $\mathrm{KM}$ 筋注後の血中濃度を 測定し，腎機能正常者に比し明らかに蓄積傾向があるこ とを確認したが，人工透析によつて除去可能であること を明らかにし得た。

4。家鬼を用いて KM 投与を行ない，腎に対する影 響を経日的に追究し，さらに実験的腎障害家鬼に同様の 操作を加えて比較検討した 結果，次のごとき成績を得 た.

1） KM $50 \mathrm{mg} / \mathrm{kg} / \mathrm{day} 20$ 日連続筋注では腎機能如何 にかかわらず，皃とんど影響がなかつたが，300 $\mathrm{mg} / \mathrm{kg} /$ day では腎障害を萀起するものが多く大半はそのために 死亡した。

2）腎障害を来した場合には尿中潜血の出現，尿蛋白 の增加（30mg/dl以上）をみて和り。これらは腎障害発生 の有力な指標となり得ることを知つた。

3）かかる腎障害を防止するためには KM 血中蓄積 の有無を予め知つて和くことが必要で，このため私の考 案した全血ディスクによる $209 \mathrm{P}$ 表面塗洙法は有用であ つた。

4）以上のごとき諎点を考慮した上注意して使用すれ ば KM と云えども腎障害患者江投与可能であり，尿路 感染症治療㓮としての優秀性を考学れば、いたずらにこ れを禁忌とする必要はないと考觉る。

本実験の要旨は第 15 回日本化学療法学会総会 ${ }^{14)}$, 第56 回日本泌尿器科学会総会 ${ }^{15)}$ とて発表した。

稿を終るにあたり恩師百瀬教授の御指導，御校閲を深 謝し，格別の御助力を頂いた坂本助教授。熊沢，樽橋。 高松の三博士ならびに教室員各位に感謝致します。

\section{交献}

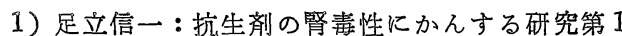
部動物実験。慈医大誌，80，332, 1965。

2) 足立信一：抗生剂の腎毒性にか九する研究第 II 部臨床研究。慈医大誌, 80,490, $1966 。$

3) Atuk, N.O., Mosga, A., K.unin, C.: Ann。 Intern. Med., 60, 28, 1964.

4) Berger, S.H., Bergstrom, W. H., Wehrle, P.F.: Antibiot. Ann., 684, 1958-1959.

5) Boger, W.P., Gavin, J.J.: Antibiot. Ann., 
677, 1958-1959.

6) Bush, I.M., Orkin, L. A., Winter, J.: J. Urol., 94, 168, 1965.

7) Cormia, F.E, et : (越島新三郎, 鈴木栄一, 平 松稔夫，診断と治療，42，534，1954）上り引 用.

8）江本㑆一, 梄橋勝利, 日高正昭, 熊沢浄一：皮 と泌, 28, 310, 1966.

9) Fingold, S.M.: Arch. Intern. Med., 104, $15,1959$.

10）福井一郎, 谷村実一, 西垣定雄: 臨床皮泌, 18, 437, 1964.

11）古沢太郎, 東登伎雄, 三品輝雄, 村上剛, 保井 明泰, 高橋徽 : 泌尿紀要, 14, 230, 1968.

12) Greenberg, P.A., Sanford, J.P.: Ann. Intern. Med., 66, 465, 1967.

13) Herrold, R.D.: J. Urol., : 79, 1010, 1958.

14) 日高正昭, 樽橋勝利, 能沢浄一, 百瀬俊郎 : Chemotherapy, 16, 378, 1968.

15）日高正昭, 樽橋勝利, 熊沢浄一, 百瀬俊郎 : 日 泌尿会誌, 59, 797, 1968.

16）稲田勉, 本郷美弥, 宮川美保子: 泌尿紀要, 11, 237, 1965.

17）金沢裕, 宮村定男, 倉又利夫 : J. Antibiot. Ser. B., 13, 295, 1960.

18）加藤篤二 : Chemotherapy, 10, 335, 1962.

19）加藤篤二, 沢西謙次, 岡部達士郎 : 日本医師会 雑誌, 58, 1429, 1967.

20）河田幸道, 田原達雄, 水谷栄之, 宮村隆三, 西 浦常雄: Chemotherapy, 16, 69, 1968.

21）北本治, 深谷一太, 橋田晃, 川島明, 本間久枝 : J. Antibiot Ser. B., 15, 1, 1962.

22) Kleeman, C.R., Maxwell, M.H.: A review. Quin, E.L. and Kass, E.H., Biology of Pyelonephritis (Herry Forrd Hospital international Symposium) p. 631-646.

23）小林長泰, 高木乾一郎：日泌尿会誌，57, 119, 1966.

24）熊沢浄一 : 福岡医誌, 54, 1072, 1963.

25) 熊沢浄一 : 福岡医誌, 54, 1084, 1963.

26) Kunin, C.M.: Ann. Intern.Med., 67, 151, 1967.

27) Kunin, C.M., Finland, M.: Arch. intern. Med., 104, 1030, 1959.

28) Kunin, C.M., Finland, M.: J. Clin. Invest., 38, 1509, 1959.

29）黒川一男：日泌尿会誌，46，415，1955.

30）久世益治, 柏木崇, 大北純三, 小宮俊秀, 仁平 寛已：泌尿紀要，12，291，1966。
31）牧野昌彥: 泌尿紀要, 14, 351，1968.

32) Mc Curdy, P.R.: Blood, 21, 363, 1963.

33) Melnick, I., Litvak, A.S.: J. Urol., 96. 257, 1966.

34) 百瀬俊郎, 沢熊浄一, 楢橋勝利, 日高正昭 : Chemotherapy, 16, 466, 1968.

35) 百瀬俊郎, 熊沢浄一, 樽橋勝利, 日高正昭 : 皮 々泌, 29, 827, 1967.

36) 百瀬俊郎, 熊沢浄一, 樽橋勝利, 日高正昭 : 臨 床々研究，44，2158，1967.

37）百瀬俊郎, 坂本公孝, 楢橋勝利, 日高正昭, 平 田耕造, 熊沢浄一：皮と泌, 28, 318, 1966.

38）樽橋勝利：日泌尿会誌，58，1115, 1967.

39）西村洋司：日泌尿会誌，53，265， 1962.

40）西浦常雄, 横山繁 : Chemotherapy，9，446, 1961.

41）野村孝義 : Chemotherapy， 7, 169，1959.

42 ）岡直友, 塚本俊雄 : 日泌尿会誌, 52, 759, 1961.

43）大井好忠：皮と泌，27，299，1965.

44) Ory, E.M., Williams, Jr., T.W., Camp, F. A., Regester, R.F., Morgen, R.O.: Ann. N.Y. Acad. Sci., 132, 933, 1966.

45）坂崎利一：日本栄善化学, 東京, 1961.

46) Seneca, H., Peer, P.: J. Urol., 94, 78, 1965.

47）志田圭三 : 診断と治療, 48, 778, 1960.

48）宾戸仙太郎：日泌尿会誌, 57, 967, 1966.

49）杉本克治, 中山宗文, 中島順子 : 泌尿紀要, 11 , $1163,1965$.

50) 高井修道, 安達徹, 永井竜男 : 札幌医誌, 28 , 54,1965

51）高安久雄, 寺脇良郎：部断と治療，53，1002, 1965.

52) Takeuchi, T., Hikiji, T., Nitta, K., Yamazaki, S., Abe, S., Takayama, H., Umezawa, H.: J. Antibiot. Ser. A., 10, 107, 1957.

53）上田泰, 中村昇：ファルマシァ. 4, 179, 1968.

54）占部慎二 : 皮々泌, 23, 357, 1961.

$55 ）$ 占部慎二：日泌尿会誌, 57, 236, 1966.

56）占部慎二：日泌尿会誌, 57, 250, 1966.

57) Winfield, M., Crisp, G.O., Maxwell, M.H., Kleeman, C. R.: Ann. N.Y. Acad. Sci., 76, 140, 1958.

58) Wright, W.W., Welch, H.: Antibiot. Ann., $61,1959-1960$.

59）山本忠次郎, 鳴海敏夫, 伊藤孝義, 広瀬文雄, 增永 昭佳，滝本至得：日泌尿会誌，58，268，1967，

60）吉田泰 : 泌尿紀要, 13，373，1967.

（昭和 44 年 8 月 28 日受付, 特別揭載) 